\title{
MuILR
}

\section{IMPACT OF SELECTED ENERGY CONSERVATION TECHNOLOGIES ON BASELINE DEMANDS}

\author{
A. DOERNBERG
}

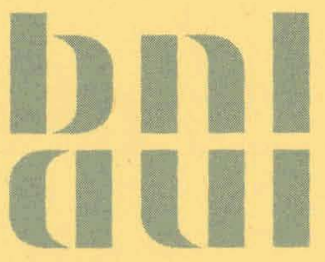

September 1977

TECHNOLOGY ASSESSMENT GROUP NATIONAL CENTER FOR ANALYSIS OF ENERGY SYSTEMS

BROOKHAVEN NATIONAL LABORATORY ASSOCIATED UNIVERSITIES, INC. UNDER CONTRACT NO. EY-76-C-02-0016 WITH THE UNITED STATES DEPARTMENT OF ENERGY 


\section{DISCLAIMER}

This report was prepared as an account of work sponsored by an agency of the United States Government. Neither the United States Government nor any agency Thereof, nor any of their employees, makes any warranty, express or implied, or assumes any legal liability or responsibility for the accuracy, completeness, or usefulness of any information, apparatus, product, or process disclosed, or represents that its use would not infringe privately owned rights. Reference herein to any specific commercial product, process, or service by trade name, trademark, manufacturer, or otherwise does not necessarily constitute or imply its endorsement, recommendation, or favoring by the United States Government or any agency thereof. The views and opinions of authors expressed herein do not necessarily state or reflect those of the United States Government or any agency thereof. 


\section{DISCLAIMER}

Portions of this document may be illegible in electronic image products. Images are produced from the best available original document. 
BNL-50745

UC-95c

(Energy Conservation-Systems Modeling and Performance Assessment - TID-4500)

\title{
IMPACT OF SELECTED ENERGY CONSERVATION TECHNOLOGIES ON BASELINE DEMANDS
}

\author{
A. DOERNBERG
}

September 1977

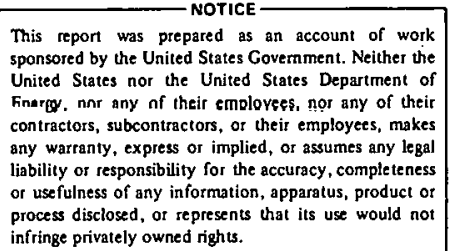

TECHNOLOGY ASSESSMENT GROUP NATIONAL CENTER FOR ANALYSIS OF ENERGY SYSTEMS

BROOKHAVEN NATIONAL LABORATORY UPTON, NEW YORK 11973 
NOTICE

Thls report was prepared as an account of work sponsored by the United States Government. Neither the United States nor the United States Departmcnt of Energy (DOE), nor any of their employees, nor any of their contrastnrs, subsentractore, or their employees, makes any warranty, express or implied, or assumes any legal liability

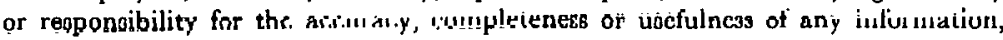
apparatus, product or process disclosed, or represents that its use would not infringe privately owned rights.

Printed in the United States of America Available from

National Technical Information Service U.S--Department of Commerce 5285 Port Royal Road Springfield, VA 22161

Price: Printed Copy $\$ 6.50$; Microfiche $\$ 3.00$ 


\section{ABSTRACT}

This study is an application of the modelling and demand projection capability existing at Brookhaven National Laboratory to specific options in energy conservation. Baseline energy demands are modified by introducing successively three sets of conservation options. The implementation of improved building standards and the use of cogeneration in industry are analyzed in detail and constitute the body of this report. Two further sets of energy demands are presented that complete the view of a low energy use, "conservation" scenario. An introduction to the report covers the complexities in evaluating "conservation" in view of the ways it is inextricably linked to technology, prices, policy and the mix of output in the economy. The term as used in this report is narrowly defined, and methodologies are suggested by which these other aspects listed can be studied in the future. 


\section{THIS PAGE \\ WAS INTENTIONALLY LEFT BLANK}


Page No.

\begin{tabular}{|c|c|c|}
\hline \multicolumn{2}{|c|}{ ABSTRACT } & \multirow{2}{*}{$\begin{array}{l}i i i \\
v i\end{array}$} \\
\hline LIST C & F TABLES & \\
\hline LIST C & F FIGURES & viii \\
\hline SUMMAR & & 1 \\
\hline $\mathrm{I}$ & INTRODUCTION & 7 \\
\hline I I & ASSESSMENT OF ENERGY CONSERVATION TECHNOLOGIES & 17 \\
\hline II -1 & RESIDENTIAL AND COMMERCIAL BUILDINGS & 27 \\
\hline A. & Demands to Year 2000 & 27 \\
\hline B. & Comparison of Baseline Energy Demands with & \\
\hline & Other Projections & 49 \\
\hline c. & Cost Inputs & 52 \\
\hline D. & Extension to BESOM & 55 \\
\hline E. & Analysis of BESOM Runs & 57 \\
\hline II-2 & INDUSTRIAL BY-PRODUCT GENERATION & 63 \\
\hline A. & Implementation schedule & 65 \\
\hline B. & Technical Parameters & 66 \\
\hline r.. & Model Run Results & 68 \\
\hline II -3 & TRANSPORTATION SECTOR & 71 \\
\hline A. & Demand to the Year 2000 & 72 \\
\hline B. & Comparison to Year 2000 Demands with Other & \\
\hline & Projections & 79 \\
\hline c. & Discussion of Demand Projections & 81 \\
\hline
\end{tabular}

APPENDIX A: Reference Energy System and Brookhaven 


\section{LIST OF TABLES}

Table No.

$$
S-1
$$

1

2

3

4

5

6

7

8

9

10

11

12

13

14

15

16

17

18

19

20
Title

Summary of Projected Services, Year 2000

Year 2000 Energy Projections

Net Removal Rates

Space Heat, Residential - Northeast

Space Heat, Residential - North Central

Space Heat, Residential - South

Space Heat, Residential - West

Cooling, Residential - Northeast

Cooling, Residential - North Central

Cooling, Residential - South

Cooling, Residential - West

Water Heating, Residential - U.S.

Light \& Power, Residential

Space Heat, Commercial

Air Conditioning, Commercial

HVAC Auxiliaries, Commercial

Light and Power, Commercial

Water Heating, Commercial

Basic Energy Demands, Residential

and Commercial Secturs

Incremental Costs, ASHRAE 90-75 versus

Conventional. Buildings

Baseline versus Conservation, Residential

and Commercial Builaings
Page No. 


\section{LIST OF TABLES}

Table No.

Title

Page No.

21 Marginal Value Analysis: Cost-Effective Additional Expenditures

61

22

Projected Growth, Transportation Sector

75

23 Transportation Efficiencies

76

24 Decreases in Unit Fuel Consumption

77

25

Transportation Mode Shares

78

26

Energy Demand, Transportation Sector

2000

80

27

Transportation Sector, Advanced Decreases in Unit Fuel Consumption 
LIST OF FIGURES

Title

$\begin{array}{ll}1 & \begin{array}{l}\text { Structure of Conservation Analysis, Year } \\ 2000 \text { Estimates }\end{array} \\ 2 & \text { Year } 2000 \text { Baseline } \\ 3 & \text { Year } 2000 \text { Conservation I } \\ 4 & \text { Year } 2000 \text { Conservation II } \\ 5 & \text { Year } 2000 \text { Revised Growth }\end{array}$

Page No.

3

18

21

22

24

- viii - 


\section{SUMMARY}

This report contains an analysis of modifications to baseline energy demands developed by Brookhaven National Iaboratory's Technology Assessment Group two years ago and described in "Sourcebook for Energy Assessment" (2). The baseline energy demands for the year 2000 are modified by introducing successively three sets of energy conservation options. These are evaluated in light of (1) measurement of their fuel savings impact on the system (2) implementation levels that are technically feasible, and (3) considerations of stocks turnover that limit rate of introduction.

The study is conceived as an application of the modelling and demand projection capability existing at Brookhaven to specific options in energy conservation. It is thus not to be viewed as a comprehensive evaluation of energy conservation potential. This concept is extremely complex and simple cost minimization - capital stock replacement models do not capture it in its entirety; an extensive general discussion of the subject is included in the Introduction of this report. Within the narrower framework utilized in this body of this report the results yield (1) cost effective implementation of improved standards in buildings and the use of cogeneration in industry resulting in an $11 \%$ arop in primary energy. (2) that the impact of increased end use device efficiences in industry and transportation result in a further arop in primary energy of $8 \%$, and (3) that even further decreases in primary energy use of $17 \%$ are achieved through a downward revision of growth rates in level of services assumed in the baseline. A summary of the level of services (i.e.. number of households, auto passenger miles etc.) for the baseline and the three cases is presented in Table S-1. Total primary energy intermediate energy and the growth rates in electric generation for these cases are shown in Figure 1. The following paragraphs contain brief descriptions of the baseline and the three cases Labeled Conservation I, Conservation II, and Revised Growth) that are analyzed 
Table S-1: Summary of Projezted Services, Year 2000

Revised

Conservation IT

Number of Households, Total, $10^{5}$ Jnits Single Family, Urahanged Single Family, Retrofits Single Family, New Standaras Multifarily, Unchanged Multifarily, New standards. Mobile Fomes

Commercial Space, Total $10^{9}$ sq ft Unchanged New Stardards

Auto, passenger miles, billion

Bus " " "

Railroad " " "

Air " " "

Truck, ton miles, tilizion

Railroad " " "

Ship " "

Air " " "

Truck, vehicle miles, billion

Industrial process heat, growth/yeär Industrial Electric,

Petrochemicals,

Aluminum,

Iron and steel.

101.70
79.00
-
14.30
-
8.40
42.00
42.00
-
4840
98
57
786
1110
1336
1844
44
259

$3.2 \%$
$4.0 \%$
$3.4 \%$
$5.2 \%$
$2.2 \%$

$$
\begin{array}{r}
101.70 \\
42.20 \\
6.45 \\
30.35 \\
7.05 \\
7.25 \\
8.40
\end{array}
$$

42.00

21.08

20.92

$3802^{(2)}$
98

98
57

786

1110

1336

1844

44

259

$3.2 \%$
$4.0 \%$
$3.4 \%$
$5.2 \%$
$2.2 \%$

\section{Growth}

101.70

42.20

6.45

30.35

7.05

7.25

8.40

42.00

21.08

20.92

$3802^{(2)}$

98

57

786

1110

1336

1844

44

259

$3.2 \%$
$4.0 \%$
$3.4 \%$
$5.2 \%$
$2.2 \%$

$2.0 \%$

$3.0 \%$

$2.0 \%$

$4.0 \%$

$2.2 \%$

(1) Approxinately 15,900 miles/vehicle per year.

(2) Approxinately 12,500 miles/vehicle per year. 


\begin{tabular}{|llll|}
\hline BASELINE, YEAR 2000 & & \\
Historical growth & & \\
High Electrification & & \\
\hline PRIMARY ENERGY : & 161 QUAD \\
INTERMEDIATE ENERGY*: & 102 QUAD \\
FLECTRIC GENERATION**: & 5.28 & p.a. \\
\hline
\end{tabular}

\begin{tabular}{|c|c|}
\hline \multicolumn{2}{|c|}{$\begin{array}{l}\text { CONSERVATION I } \\
\text { Building standards, retrofits } \\
\text { cogeneration in Industry } \\
\text { Legislated auto efficiencies }\end{array}$} \\
\hline $\begin{array}{l}\text { PRIMARY ENERGY : } \\
\text { INTERMEDIATE ENERGY* : } \\
\text { ELECTRIC GENERATION* }:\end{array}$ & $\begin{array}{r}144 \text { QUAD } \\
93 \text { QUAD } \\
4.7 \% \text { p.a. }\end{array}$ \\
\hline $\begin{array}{l}\text { CONSERVATION II } \\
\text { Blanket increases in en } \\
\text { efficiencies in indust } \\
\text { Higher efficiency impro } \\
\text { transportation modes }\end{array}$ & $\begin{array}{l}\text { use device } \\
\text { ements for }\end{array}$ \\
\hline $\begin{array}{l}\text { PRIMARY ENERGY : } \\
\text { INTERMEDIATE ENERGY*: } \\
\text { ELECTRIC GENERATION }{ }^{\star} \text { : }\end{array}$ & $\begin{array}{r}132 \text { QUAD } \\
85 \text { QUAD } \\
4.78 \text { p.a. } \\
\end{array}$ \\
\hline $\begin{array}{l}\text { REVISED GROWTH } \\
\text { Lower growth rates in } \\
\text { categories } \\
\text { No electricity to therm } \\
\text { industry }\end{array}$ & dustrial \\
\hline $\begin{array}{l}\text { PRIMARY ENERGY : } \\
\text { INTERMEDIATE ENERGY*: } \\
\text { ELECTRIC GENERATION: }\end{array}$ & $\begin{array}{r}110 \text { QUAD } \\
76 \text { QUAD } \\
2.78 \text { p.a. } \\
\end{array}$ \\
\hline
\end{tabular}

Figure 1. Structure of conservation analysis, year 2000 estimates. 
i) Baseline Energy Demand: final energy demands represent a high growth level for both energy and the economy the total primary energy consumed is 161 quads in 2000 or $2.9 \%$ growth from 1972, similar to the one that has existed in the last two decades. In this period, energy grew at some $75 \%$ of the rate of growth of GNP. which would yield a $3.9 \%$ GNP growth rate in the baseline for this period. Energy/economic planning is presently using GNP growth rates under 3.0\% for the 1985-2000 period. The baseline thus represents larger than historical. gains in energy consumption and standard of living.

ii) Conservation I: the study of two technological options, improved building standards in the residential and commercial sector, and the use of cogeneration in industry, constitute the body of this report and are labeled "Conservation I." This case, which also includes the legislated automobile efficiencies, totals 144 quads in primary energy for a savings of 17 quads. Buildings and the improved gasoline efficiency in automobiles each account for about $45 \%$ of the savings, with cogeneration some $10 \%$. The results are based on (1) applying ASHRAE 90-75 building standards to half new construction to 1985 and all. thereafter to 2000 (residentlal and commercial) plus some 6.5 million intensive retrofits in the residential sector, (2) installation of 40,000 MW of cogeneration by 2000 (based on 20 MW units) which generate some 800 trillion Btu(e), (3) applying a $25 \mathrm{mpg}$ standard on the automobile fleet by 2000 . up from a $17.9 \mathrm{mpg}$ in the baseline. The measures in (1) and (2) were evaluated with BESOM $^{*}$ using annualized capital ${ }^{*}$ Brookhaven Energy System Optimization Model 
rosts for the improvements over standard construction for build.ngs and capital investment costs in cogeneration assuming $\$ 16.50$ and $\$ 23.00$ per barrel of oil. BESOM was expanded to incorporate the necessary details. A summary of the model is presented in Appendix $A$ and the modifications are detailed in section II-1. Auto efficiencies were not evaluated with BESOM since its cost effectiveness is implicit within the political decision to legislate on the matter.

\section{iii) Conservation II: It was felt that for the sake of} completeness, other likely efficiency improvements have to be shown in the system. Because no end use costs have been calculated and no good data on stocks turnover rates exist for industry, these measures have been incorporated without further analysis. They are: improvements in end use efficiency of $10 \%$ in process heat, $20 \%$ for coal to iron and steel, 33\% for electricity to aluminum, transportation modes increase their efficiencies (per ton mile or passenger mile - could be due to management measures also) 20-30\% from 1972 levels, and autos are improved beyond mandated mileage to obtain a fleet average of $29 \mathrm{mpg}$. Auto travel is limited to 14,400 passenger miles per capita. They result in a total fuel consumption of 132 quad for a drop of 29 quad over the baseline (including the measures in Conservation I). Over one half (56\%) of this is from the transportation sector, with residential and commerical accounting for $25 \%$ and the industrial sector $19 \%$.

iv) Revised Growth: it is not unlikely that projections published by different organizations will arrive at "conservation" scenarios for 2000 totaling only 120 to 1.00 quads or lower. The lowest case presented here is considerable higher at 
132 quads, as a result of the larger growth in demand assumed in the Baseline, particularly in the industrial sector. The increase in electrification (electricity accounts for $20.7 \%$ of the total intermediate energy in the baseline, up from $10.9 \%$ in 1972) also contributes to a substantial increase in primary energy. The baseline includes large uses of electricity for low and medium heat applications (for space and process heat), and these substitutions are not consistent with a strong commitment to conserve primary energy. Therefore, a final case was prepared labeled "Revised Growth" that yields a total primary energy in the range cited above. It includes the following reductions of final demand: industrial process heat grows at $2 \%$ per year (down from 3.2\%), industrial electric drive at 3\% (growth in baseline is $4 \%$ ), petrochemicals at $2 \%$ (from $3.4 \%$ ) aluminum production at 5\% (from 5.2\%). In addition, electric space heat is kept at a roughly historical share of total households, and no electricity is sent to meet process heat demand. This scenario results in a total resource consumption of 110 quads and total intermediate energy of 76 quad for drops of 51 quad and 25 quad, respectively. Fully $50 \%$ of the drop in intermediate energy is in the industrial sector and of this percentage, nearly $80 \%$ is a result of reduced growth rates and some $20 \%$ because of increased end use efficiency. 


\section{INTRODUCTION}

Among proposed energy strategies, conservation holds the unique position of being a major element in practically all energy futures. Whether this future is viewed as heavily electrified, dominated by solar energy, or by other advanced or intermediate technologies, conservation will have a major role in any orderly transition towards new energy systems. Although not quite a misnomer, "conservation" is at best an unfortunate choice of a word that is meant in this study to represent decreases in the amount of fuel needed to perform a certain amount of work or services in our economy. The problem of semantics is nevertheless hardly trivial when we consider the disparity of outlooks on energy conservation. One economist who has been involved in this area uses the following definition: "Energy Conservation is taken to be the entire effort to shift the Nation's economy from pre-1973 trends of energy use to the pattern of energy which constitutes Energy Thrift... Energy Thrift is defined as the use of energy only where its incremental product is at least as large as the incremental social cost of the energy..."(16) It is clear that the main focus here is prices of resources and particularly the real cost of fuels. On the other hand there is an engineering outlook that describes conservation as a quasi tangible energy form: "... energy recovered from waste in the application or use of other energy forms (e.g., recycled process heat), or, savings recovered from any energy consuming device when the device is modified to improve its efficiency (e.g., the savings from adding insulation to a builaing)" (17). 
There is a conventional approach to energy conservation studies (also adopted by governmental planning agencies) in which the introduction of conservation into the system is carried out without a change in the standard of living, that is, a reduction in fuel consumption achieved through reduced output in the economy or lifestyle changes is not acceptable as conservation. This approach is ambiguous, however, because a limited tampering with the quality of the level of services such as the reduction of room temperatures in the heating season or lower speed limits for automobiles is considered a valid conservation measure, while a switch to transportation modes requiring less energy per mile travelled (i.e., mass transit) is viewed as a change in lifestyle. Indeed, such changes occur continuously in our society in response to price changes, income changes and technological change. The amount of tampering permitted while at the same time not affecting the standard of living is subjective and reflects the social and political biases of the analyst. The basis for the large range of estimates of "potentials for conservation" that exist in the literature is precisely this line between energy savings without lifestyle change on the one hand and erosion of standard of living caused by decreased energy use on the other. Even the tamest conservation option is subject to the aryument described here, and without exception all conservation technologies have an impact on the mix of output of the economy (i.e.. produce more insulation and fewer power plants) that in turn have secondary impacts on the ways people consume goods and are employed (i.e., lifestyles). 
The customary listing of conservation measures begins by separating the short term from the long term impacts and grouping them into similar kinds of options:

- Leak Plugging: reduce heat losses in buildings, recover waste heat in industry, adjust systems to run at design efficiency.

- Energy Management: reduce excess lighting, modify thermostat settings, reduce driving speed, increase loads in freight transportation.

- Modification of Use Pattern: shift to public transportation, use of small automobiles.

- Technological Improvements in New Systems and Retrofits: these can be further separated between off-the-shelf energy efficient devices and new ones that have yet to be commercial. The former include improved design in building, heat pumps, industrial cogeneration of electricity and heat. The latter include new industrial process technologies, improved propulsion systems in transportation, commercial and industrial applications of heat pumps.

- Long-term Behavioral - institutional changes: general consumer attitude towards energy thrift, reflected in life-cycle costing, product obsolescence, land use and so on.

These categories are listed roughly in order, from short term through intermediate and long term impacts, and the degree of impact on lifestyle of each group is fairly explicit. 
Absent from the list are all solar technologies, which are often included as conservation options. This is justified when conservation is defined as any measure resulting in a reduction in the use of scarce non-renewable resources. In this study the definition is less broad; solar energy becomes classified as a supply technology and thus is excluded from this assessment. Much the same argument can be made for options such as waste incineration (it can be treated as an energy resource, a waste disposal solution or broadly, "conservation"), metals recycling when proven energy wise and so forth. These choices will become naturally integrated in the energy system by their respective industries if they become economically desireable and any impact beyond these levels would be marginal.

The rate of implementation of energy conservation will either come about by means of uncontrolled forces such as increased market price or undirected changes in consumer tastes, or by government policies such as mandatory standards, allocation, rationing, and tax or subsidy measures--or a combination of these. The broad impact of these conservation measures has been the subject of numerous studies in which energy resource consumption is reduced by fractions ranging from $6 \%$ in the short term to $40 \%$ below "business as ușual" growth. The results of some of these studies show the following impacts: 
- National Petroleum Council (23): studied all energy demand sectors and added the impact of several measures for the 1974 to 1978 period. Resulted in reductions of $5.7 \%$ to $7.8 \%$ in primary energy, with $100 \%$ and $150 \%$ primary energy price increase respectively.

$\therefore$ United Nations Economic and Social Council (24) this study views the average efficiency of end use energy utilization increasing by $21 \%$ (from .42 to .51) as "practically possible" by the early 1990's and by. $31 \%$ (to .55) as a "maximum level attainable" by that date. For the energy sector as a whole, including conversion, transmission and most importantly extraction, the average efficiency increases are 33\% "practically possible" and 100\% "maximum".

- Lawrence Berkeley Laboratory (25) : specific energy requirements could be reduced by 33 $40 \%$ over the next few decades at cost savings to energy users - having only a slight effect on lifestyle as well. This estimate was arrived at on a process by process basis, evaluating potential efficiency improvements and usage pattern changes.

- Marquis seidel ${ }^{(26)}$ : an econometric analysis of the manufacturing sector yields a $40 \%$ decline in energy use brought about by an increase in real energy prices of $44 \%$ with an impact on decreased earnings of only $2 \%$. 
- Rand Corporation (5): this study on the potential for conservation in the residential sector separates the possible measures into five groups according to their cost effectiveness and whether they would have to be mandated or voluntary. The implementation of two of these groups, standards for new buildings and for appliances (both are mandated and are cost effective in some individual cases and not in others), yield primary energy savings of $20 \%$ by 1990 ( 3.5 quads) and $24 \%$ by 2000 (4.5 quads).

In goneral, analyses of "potential for conservation" and projections of energy consumption under a "conservation scenario" are beset by a series of methodological uncertainties. This is due to the difficulty in making explicit some complex interactions among different elements. The most important to be able to separate are:

1) Price and income induced modifications to energy demand resulting in changing outputs in the economy.

2) The effect of energy prices on the implementation of energy conserving technologiés.

3) Fuel savings resulting from straighttorward use of energy thrifty devilces which are cost effective at present fuel prices. 
4) Legislated or other type of mandated energy performance standards.

5) Secondary effects of conservation brought about by shifts in output of industry. If the economy produces more insulation and fewer power plants, industrial use of fuels is affected.

A general methodological framework has not been developed that enables us to distinguish among cutbacks in energy due to the different factors listed above but individual analytical techniques are available and can be quite useful. In order to maintain a focus in this study it was decided to restrict the analysis to measures that fall in 3) above - technological improvements that are cost effective. Thus, in no way does this study encompass an overall "potential for conservation." Other aspects of conservation could be covered in future studies using the following techniques:

i) The change in output in the economy caused by price and income induced modifications to energy demand (1) above) can be studied with an integrated model of energy and the economy such as the Combined 110 Sector Input/Output Model and the economic activity models at Data Resources, Inc. (27). Essentially this same modelling apability can be utilized to analyze the secondary effects of conservation due to shifts in the mix of goods towards energy thrifty products (5) above).

ii) The effect of energy prices on the speed of implementation of energy ronserving tcchnologies (2) aluuve) can be studied with demand models such as Hirst's (28) for the residential sector in combination with Brookhaven's Energy System 
Optimization Model (BESOM) (10) that provides shadow prices as input to the demand model.

iii) The impact of new technologies, 3) above, and also 4), can be studied by detailed process analysis. As can be seen in this report, the buildings sector and the transportation sector can be readily modelled, while the industrial sector requires a major effort.. At present, work is being funded by ERDA's Division of Conservation at Brookhaven for the development of energy flow charts by industrial activities (iron and steel, pulp and paper, industrial chemicals) for state-ofthe-art and new processes that will resolve the uncertainties in the area of potential for conservation in industry.

The "baseline" energy demands without conservation against which the gains from conservation are measured have to be specific as to a schedule of assumed price increases, an inclusion or exclusion of legislated efficiency standards, etc. Extreme uncertainty exists regarding any projection devoid of conservation. One approach would be to assume pre 1973 price levels and select as a "baseline" a projection made at that time. There are fortunately two such pairs of projections, both with pre-embargo and post-embargo estimation of energy demand in the year 2000 using similar methodologies. One pair ( 1 and 4 in Table 1) was made for the Bureau of Mines and is based on trend correlation, and the other pair (2 and 5 in Table 1) was made at Brookhaven National Laboratory based on specitic energy requirements at a process level. They arc presented in Table 1 together with another "historical growth" projectiun by the l'ord Energy Policy Project. Both 1972 projections can be assumed to contain no conservation, while the later projections are 
Table 1: Year 2000 Energy Projections

\begin{tabular}{ccc} 
& Total & Electric \\
Year of & $\begin{array}{c}\text { Resources } \\
15\end{array}$ & $\begin{array}{c}\text { Generation } \\
15\end{array}$ \\
Publication & $10^{15}$ Btu & $10^{\text {Btu }}$ \\
\hline
\end{tabular}
(1) Dupree \& West
1972
191.9
30.7
(2) AET-8
1972
177.0
27.3
(3) Ford, Historic growth
1974
186.7
27.1
(4) Dupree \& Corsentino
1975
163.4
29.5
(5) BNL
1975
163.0
23.6

(1) W. Dupree and J. West, "United States Energy through the year 2000," U.S. Dept. of Interior Dec. 1972.

(2) Associated Universities Inc, "Reference Energy Systems and Resource Data for Use in the Assessment of Energy Technologies," AET-8, April 1972.

(3) Ford Energy Policy Project, "A Type to Choose; America; Energy Future;" Cambridge, Mass., 1974.

(4): W. Dupree and J. Corsentino, "United States Energy through the Year 2000, (Revised)," U.S. Dept. of Interior Dec. 1975.

(5) M. Beller, Editor, "Sourcebook for Energy Assessment," Brookhaven National Laboratory, December 1975. 
considered to reflect the price increases of the 1973-1974 period. These later projections (published in 1975) can serve as a "baseline" with little or no technologically induced conservation that at the same time is not an extrapolation of historic growth and reflects post 1973 price increases.

In general, previous conservation studies have assumed potential energy savings with little consideration of the costs of obtaining these savings. Also, a traditional approach has been to tack on the energy savings based on educated guesses and intuition (i.e., increase process heat efficiencies by $15 \%)$. This study employs for two of the technologies studied (improved building standards and industrial cogeneration) Brookhaven's Energy Systems Optimization Model, which selects among options available in a systematic, minimum cost basis. Thus, for a given upper bound assumption, or implementation level (for improved building construction and cogeneration schemes), the model will choose some, all or none of that option dependending on the availability and cost of all competing technologies, and fuel prices. In addition, the study incorporates demand reductions in the transportation and industrial sector which are analyzed in a Reference Energy System format, without explicitly stating costs of the improvements or the energy prices at which these become feasible. They are included so as to obtain complete pictures of energy futures that incorporate energy conservation. 'l'he mechanisms used to attain these modiflcations to the baseline demands and their consequences on employment and income distribution are not addressed here. 
II. ASSESSMENT OF ENERGY CONSERVATION TECHNOLOGIES

The baseline projection for the year 2000 used in the study is essentially the one in "Sourcebook for Energy Assessment" with the exception of the residential, commercial, and transportation final demands, for which the baselines used are computed in Sections II-1 and II-3 that follow. Figure 2 depicts a modified Reference Energy system for this year 2000 baseline. The entire supply and electric conversion sectors are omitted because this study is concerned with final demands and there is a deliberate deemphasis of the supply sector. As indicated in the introduction, also left out are all solar technologies as well as new conversion devices such as heat pumps and electric cars. Any of these can be later added to the Reference Energy System presented here for given implementation levels. The conservation options chosen for evaluation compete against existing technologies and fuels that meet the required energy demands in the baseline. The underlying growth assumptions implicit in the baseline are outlined in the following paragraphs.

The final energy demands presented in Figure 2 represent a high growth level for both energy and the economy. The total primary energy consumed (161 quads) represents a $2.9 \%$ growth rate from 1972* which is similar to the one that has cxiated in the last two decades (between 1955-1965 and 1965-1975). This was a period characterized by high growth, and applying the relationship that has held in that period of energy growth being $75 \%$ that of GNP, we obtain a growth rate for the latter of 3.9\%. This is higher than the $3.0 \%$ presently used in energy/economic

*Using 1975 as a base, the yearly growth rate is $3.3 \%$ 


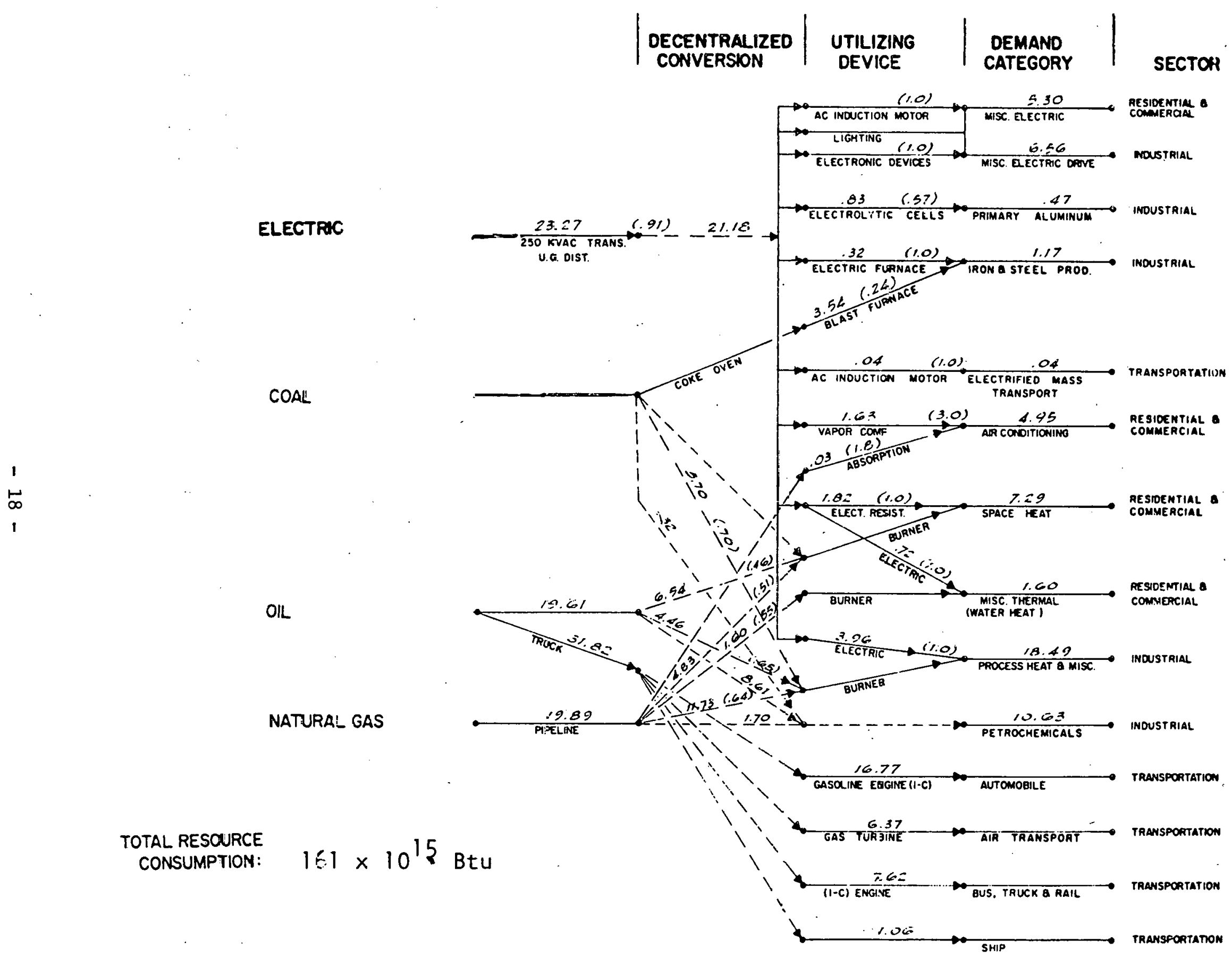

Figure 2. Year 2000 baseline. 
planning. The implied energy per capita growth rate in the baseline is $2 \%$ per year, which is larger than the historical 1.4\%. Even taking into account the larger conversion losses in the 2000 system due to higher electrification and coal gasification, the baseline represents larger than historical gains in energy consumption and standard of living.

The growth rate is largely attributable to the electric sector. In terms of intermediate energy, the residential and commercial sectors grow at $1.3 \%$ and the transportation sector at $2.4 \%$. The industrial sector grows at approximately $3 \%$, but it contains nearly 4.0 quads of electricity that are introduced for "phantom" uses mainly to boost the growth in electric generation. The rationale for this is to close the differential between the historical growth of the electrical sector of $7 \%$ and the one derived in the projection, which as represented in Figure 2 is up to $4.7 \%$ per year (1972 base; with 1975 as a base it is $5.2 \%$ ). Another view of the baseline is shown in Table 28, which lists the level of services provided by this projection. The number of households, square feet of commercial space, growth rates for industrial activities and level of services in the transportation sector are the parameters explicitly used to obtain the baseline energy demands. Table 28 also includes the modificatiuns, if any, to the level of services in the conservation futures utilized in their study. These cases are presented in the following paragraphs.

Three conservation packages are successively introduced into the baseline. The first, Conservation $I$, is a detailed assessment of a set of technological options, and it consti-. tutes the body of this report. Implementation levels and costs are specified and the system is allowed to select all or none 
of these options on a minimum cost basis. The second package, Conservation II, allows for across the board increases in end use efficiencies. This ad hoc approach brings our scenario in line with other studies on conservation done similarly and for which data unavailability precludes an andysis such as performed on the first group of options. Lastly, the high growth rate in final demand of the industrial sector mentioned above is lowered in a Revised Growth case. Here all assumptions in Conservation I and II are combined with low final demands to obtain a lowest total primary energy case. A schematic representation of the progression from baseline to lowest total enerby is presented in Figure 1.

Conservation I (Figure 3) includes: 1) application of ASHRAE 90-75 standards in new buildings plus retrofitting of a fraction of single family homes affecting all residential and commercial uses (space conditioning, water he ating, and electric power); 2) the use of cogeneration of electricity and heat by industry; and 3) the effects of the Energy Policy Act on automobile efficiency. The options included in this group present no technological problems and their implementation rates are carefully studied. Sections II-1 through II-3 contain this analysis. The likelihood of achieving these gains is good: auto mileage is mandated by legislation and so are ASHRAE building standards in a growing percentage of states. The only obstacles are institutional, especially for cogeneration.

Conservation II (Figure 4) includes all options in Conservation I and in addition: 4) improvements in end use efficiency of $10 \%$ in process heat, $20 \%$ for coal to iron and steel, and $33 \%$ for electricity to aluminum (representing a decrease from 8 


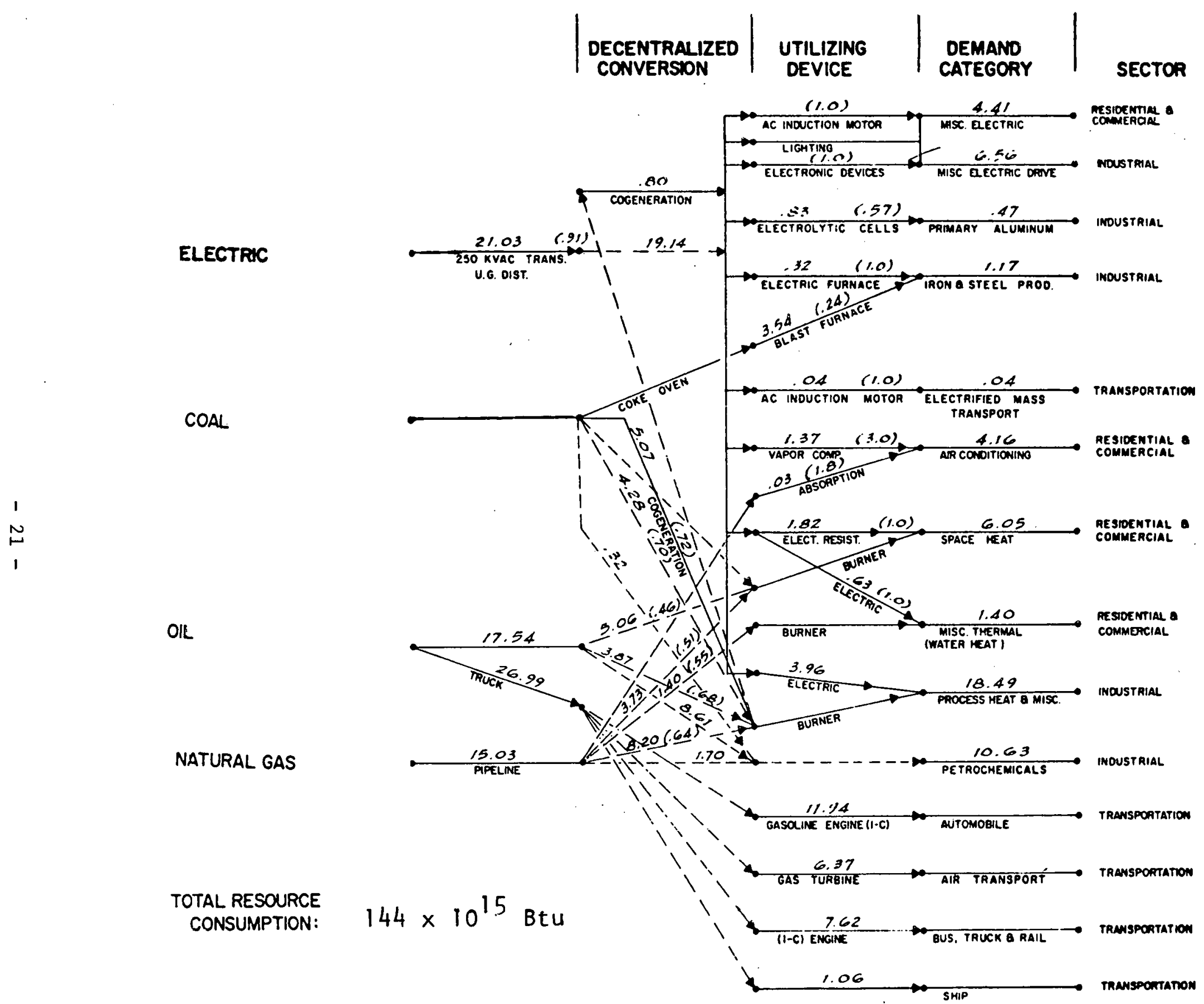

Figure 3. Year 2000 conservation I. 


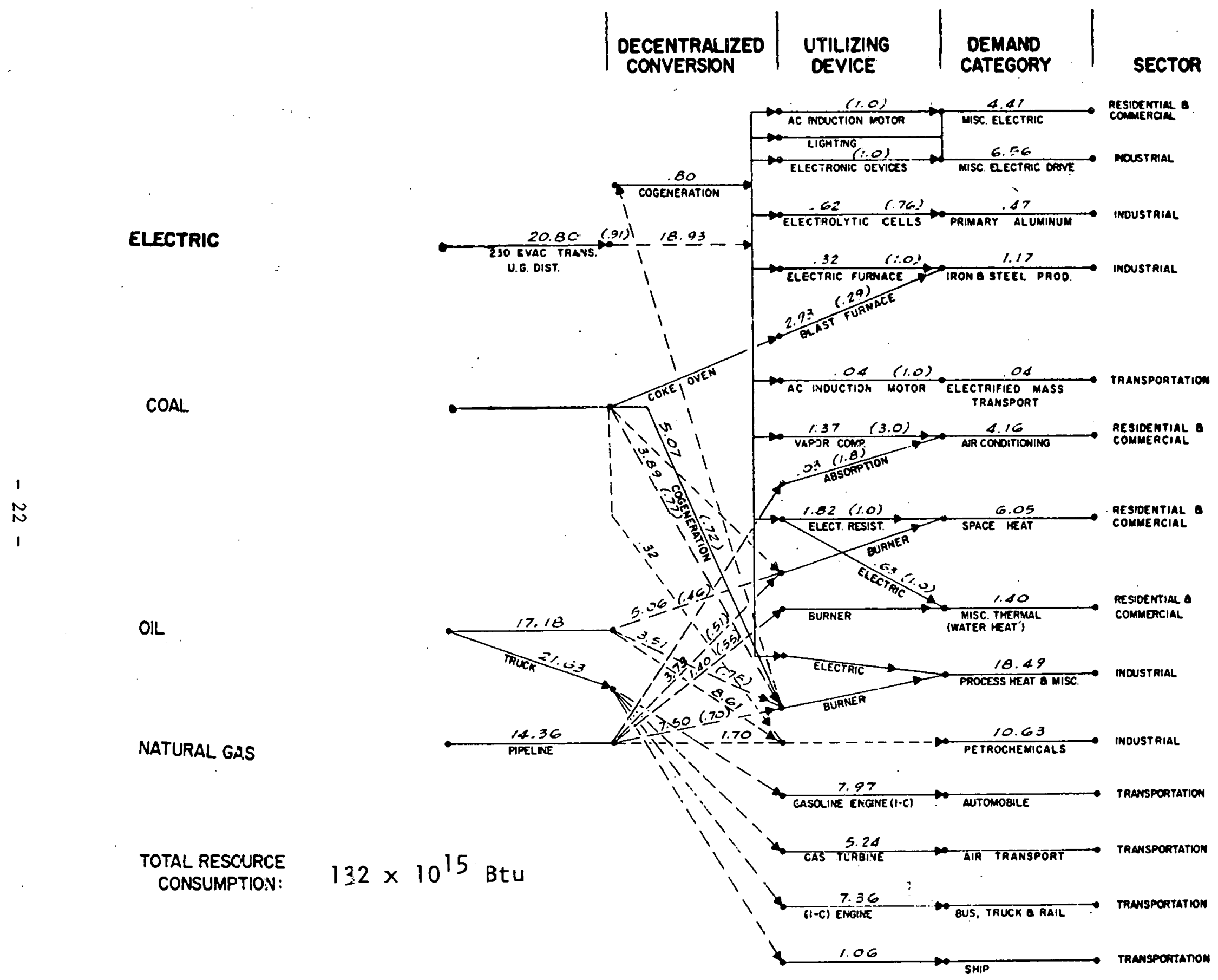

Figure 4. Year 2000 conservation II. 
$\mathrm{kWhr} / 1 \mathrm{~b}$ to $6 \mathrm{kWhr} / \mathrm{lb}$ ). Finally, 5) transportation modes increase their efficiency 20-30\% from 1972 levels, and autos are improved beyond mandated mileage to obtain a fleet average of $29 \mathrm{mpg}$ (Table 27). In addition, total automobile passenger miles deviate from historical trends because of saturation of per capita yearly travel. This is explained in section II-3. No cost estimate is attached to this package. The improvements in the industrial sector hinge on capital availability for investment in new equipment. In part, the efficiency gains are based on existing technologies, as in the case of aluminum, while in iron and steel it is a combination of on-the-shelf and new developments. In the transportation sector, the assumptions for the range of modes are uncertain; the government is at presend mainly funding research on the automobile.

At this point it is difficult to ascertain the GNP impact, if any, of the conservation measures introduced into Conservation. I and II. The levels of services provided are identical to the ones in the baseline except for auto travel in Conservation II which was cut back slightly (Table 28). The decrease in direct fuel use has a negligible effect on total GNP, and the changes in capital and labor productivity from the introduction of cogeneration or new building standards will have to be left to future studies. At any rate, the GNP growth rate implied in Conservation I and II cannot be too different from the one in the baseline.

Revised Growth (Figure 5): contains all conservation and efficiency improvements included in Conservation II (Figure 4) with the following modifications to final demand: industrial process heat grows at $2 \%$ per year (down from $3.2 \%$ ), industrial 


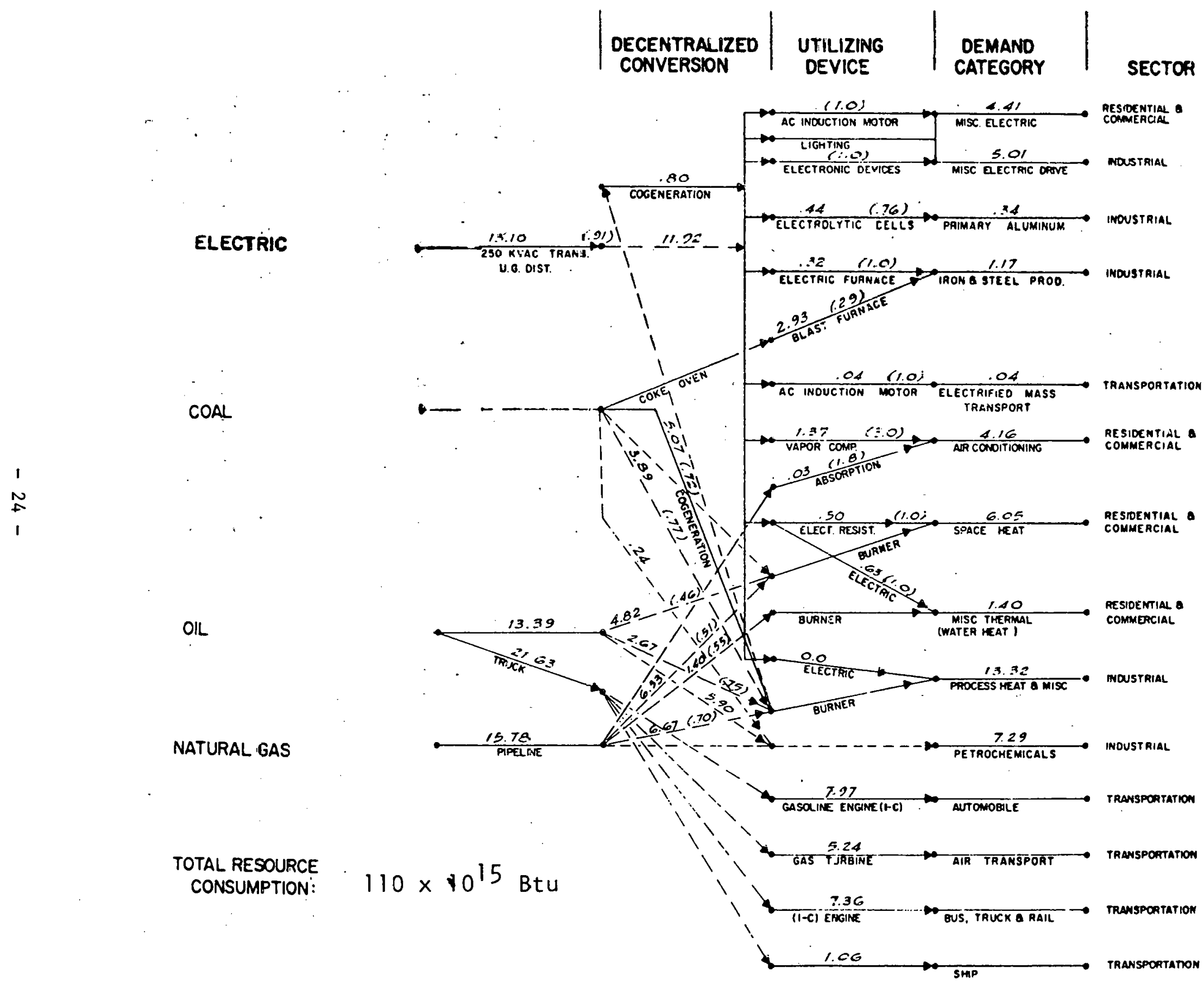

F-gure 5. Year 2000 revised growth. 
electric drive at $3 \%$ (growth in baseline is $4 \%$ ), petrochemicals at $2 \%$ (from $3.4 \%$ ), aluminum production at $4 \%$ (from $5.2 \%$ ). In addition, electric space heat is kept at a roughly historical share of total households and no electricity is sent to meet process heat demand. The rationale for not maintaining quasihistorical exponential growth rates in the industrial sector is in part justified by drawing a parallel with the assumptions in the other sectors. Residential consumption is explicitly tied to households and specifies unit energy demands and saturations. The transportation sector incorporates a limit to the time per day spent in an automobile. One may assume that "ceilings" also exist in per capita energy consumption in the industrial sector, and that by the year 2000 the economy would gradually be approaching them. Infinite exponential growth at nearly the levels prevalent in the sixties, as assumed in the baseline, is as likely to be in error as the assumption of the existence of a "ceiling."

The drop in the GNP growth rate implied in this revised growth case can at this point only be derived in a most ad hoc fashion. As was mentioned in the Introduction, the modelling capability to obtain these impact exists. A low growth case prepared for ERDA's Division of Planning, Analysis and Evaluation recently by the National Center for Applied Systems Analysis (Case Set 1B) shows similar total primary energy consumption to the revised growth case in this study and has a GNP growth rate of $2.5 \%$. There are differences in these configurations, however. Case Set $1 B$ has a lower demand of energy by the residential and commercial sector and $a$ higher one in the industrial sector of about 17\%. Considering that GNP growth is more sensitive to energy demand in the industrial sector than in the direct consumption sector, the GNP for this revised growth case would probably be under $2.5 \%$ per year. 


\section{THIS PAGE}

\section{WAS INTENTIONALLY LEFT BLANK}


II-1. RESIDENTIAL AND COMMERCIAL BUILDINGS

This section focuses on the changes in energy demand brought about by improved building designs. For new construction these improvements correspond to the recent ASHRAE Standard 90-75, for which a detailed analysis on energy demand and construction costs was made by A. D. Little, Inc. (1) The impact and costs of retrofitting are derived from other sources. This section describes the assumptions on housing stocks, unit energy demand and costs that went into the analysis, followed by a description of the modifications to BESOM needed to incorporate the detailed demand structure and, lastly, an analysis of the economics of the improvements in construction as obtained from the model.

A. Demands to the Year 2000

A set of demand projections to the year 2000 were developed to serve as a baseline against which the improved construction could be assessed. Demands are disaggregated by processes, i.e.. space heat, air conditioning, water heat; and miscellaneous electric uses. These categories are consistent with previous energy projection studies performed at the National Center ${ }^{(2,3)}$ but new projections were required for this analysis to deal at the level of unit energy demands for several building types in different regions. Underlying assumptions of growth of building stocks and saturation levels were kept consistent with the projections in (2) and (3); a detailed comparison of these referenced projections and the baseline obtained here is included in section $B$. The following paragraphs contain a description of the component that formed the basis for the projections: housing stocks, unit energy demands and saturations. 


\section{A.I Building Stocks}

The driving factors behind the growth in demands are the building stocks. As a first step, a schedule of construction and demolition by building type and region was obtained out to the year 2000. Total stocks by region and housing type for the residential sector are consistent with (3) and for the totals in the commercial sector with (2). The breakdown between new construction and surviving stock is obtained from demolition rates adopted from FEA's Project Independence Task Force Report. (4) The removal rates used are presented in 'lable 2 . New construction is then obtained as the difference between projected existing inventory and surviving (pre-1972) stock. The underlying assumption is that no post 1972 construction gets removed in the 1972-2000 period.

Along with the breakdown of the building stock between new and surviving, key assumptions must be made on number of retrofits, and new construction adopting improved designs. This is ideally performed, within reasonable constraints, by the optimization model, i.e., given costs and energy savings, have the cost. minimization algorithm decide the number of units of each type. As a first cut, however, they were set exogenously. As will be seen when the results are analyzed, the fixed schedule of building types does not diminish the usefulness of the model results.

For the residential sector it was assumed that one half of the new construction in the 1972-1985 period and 11 now cunstruction in the 1985-2000 period meet the ASHRAE 90-75 Standard. In addition, of these units, $1 \%$ in the 1972-1985 and 10\% in the 1985-2000 period are even more tightly designed (reterred to 
Table 2: Net Removal Rates

$$
\begin{aligned}
& \text { Residential Sector* } \\
& \text { 1972-1985 1985-2000 }
\end{aligned}
$$

Northeast

Single family Multifamily Mobile home

$\begin{array}{ll}.11 & .13 \\ .25 & .27 \\ .52 & .54\end{array}$

North Central

Single family Multifamily Mobile home

South

$\begin{array}{lll}\text { Single family } & .20 & .15 \\ \text { Multifamily } & .39 & .27 \\ \text { Mobile home } & .47 & .54\end{array}$

West

$\begin{array}{lll}\text { Single family } & .26 & .18 \\ \text { Multifamily } & .39 & .36 \\ \text { Mobile home } & .65 & .54\end{array}$

\section{Commercial Sector}

$$
\text { 1972-2000 }
$$

Offices

$1.47 \%$ per year

Retail

1.52

"

$"$

Schools

$1.35 "$ "

Other

1.36

36

54 
as "super" design in this study), giving them the characteristics of a well retrofitted home. For rates of retrofits there is a wide range of estimates made on their implementation levels-there are even large uncertainties on the total carried out in the 1974-1976 period. A very conservative figure was chosen in this assessment of $1 \%$ per year of the stock of pre-1972 single family homes existing in 1972 through 1985 and no retrofits thereafter. As described in section C, such retrofit is intensive and costly and the rationale for discontinuation after 1985 is that by then the stock has become aged, making the decision to invest less likely. In al1, some 6.5 million units become retrofitted at this rate, or some 850,000 units per year if it is all performed starting in 1978. This is half the number of new units normally scheduled to be built in an average year.

For the commercial sector it was assumed that $50 \%$ of the new construction in the period 1972-1985 and all construction after 1985 adopt ASHRAE 90-75. No retrofits were included.

Tables 3-17 summarize the inventories of building types in 1972, 1985, and 2000 derived from the assumptions descrihed. here. The totals for both residential and commercial buildings are consistent with previous energy projections for 1985 andis 2000 reference years in (2). There is a divergence, however, in the breakdown among single family and multifamily homes. The reduced share of multifamily units presented here (as compared with (2)) is more realistic and was obtained from more recent projection work (3).

\section{A.2 Unit Energy Demands}

The energy demand in buildings is broken down into four activities: space heat, water heat, air conditioning, and 
miscellaneous electric uses. The latter includes lighting, refrigeration, appliances, and auxiliary HVAC equipment for commercial buildings. Smaller uses such as cooking and clothes drying are not explicitly modeled.

For each building type in Tables 3-17 (there are 48 different ones including the regional breakdown), a unit basic energy demand is defined for all demand activities. Basic energy is the amount of heat or power actually obtained from the fuels delivered to the building, i.e., delivered energy times end use device efficiency. The end use devices are the furnaces, water heaters, air conditioners, lighting fixtures and so on, and although in the model their conversion efficiencies are not explicitly changed, their improvements are reflected in the unit energy demands. They are taken from the sourcebook (2). The unit demands for space heating are derived from (3), while all others are obtained from the ASHRAE 90-75 assessment study (1). This study tabulates energy demands in terms of actual yearly fuel requirements, but fuels are specified (oil heating in the Northeast, gas elsewhere, electric for other uses), thereby permitting the computation of basic energy demand. The surviving (and unchanged) building stocks were assumed to have the same unit energy requirements as the new units built with present standards (pre ASHRAE 90-75, or what (1) calls "conventional" buildings). While this might overstate their demands because new construction tends to be more spacious than the average pre 1972 unit, the use of lower saturation levels for these units compensates for this effect on air conditioning and appliance requirements.

The decreases in unit basic energy are derived for ASHRAE 90-75 designed buildings from (1) for all demand activities. 
TABLE 3

REGION: NORTHEAST

DEMAND CATEGORY: SPACE HEAT, EESTDENTIAL

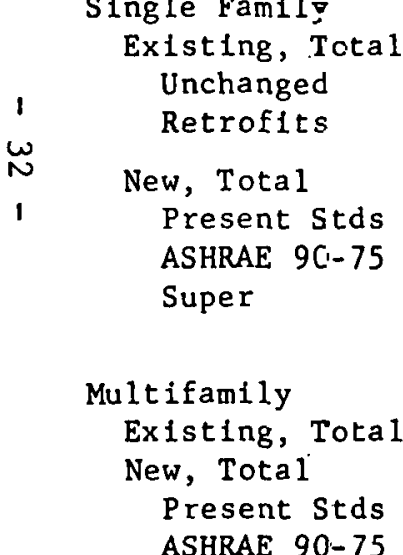

12.12

1.0

i0.8

9.31

1.49

3.7

1.35

1.32

Satu-

(4)

2000

MM Units

(5)

Satu-

ration

(6)

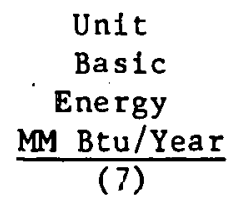

Impact

(\% of

Unchanged

Buildings)

(8)

Add1tiona 1

Cost

/Unit

(9)

MobLle Homes

9.4

7.91

1.0

63.

7.5

41.

65.6

0

L.85

5.27

.38

1. 0

63.

54.

100.

85.4

$\$ 1008$

41.

$65: 6$

0
$\$ 176$

$\$ 705$

.25

3.54

1.0

$$
\begin{aligned}
& 2 . ? \\
& 1.8
\end{aligned}
$$

1.0
L. 0

1.9

.9
2.3

1.2

23.2

15.91

19.9
26.

26.

11.

42.6

53.

TOTAL 
TABLE 4

REGION: NORTH CENTRAL

DEMAND CATEGORY: SPACE HEAT, RESIDENTIAL

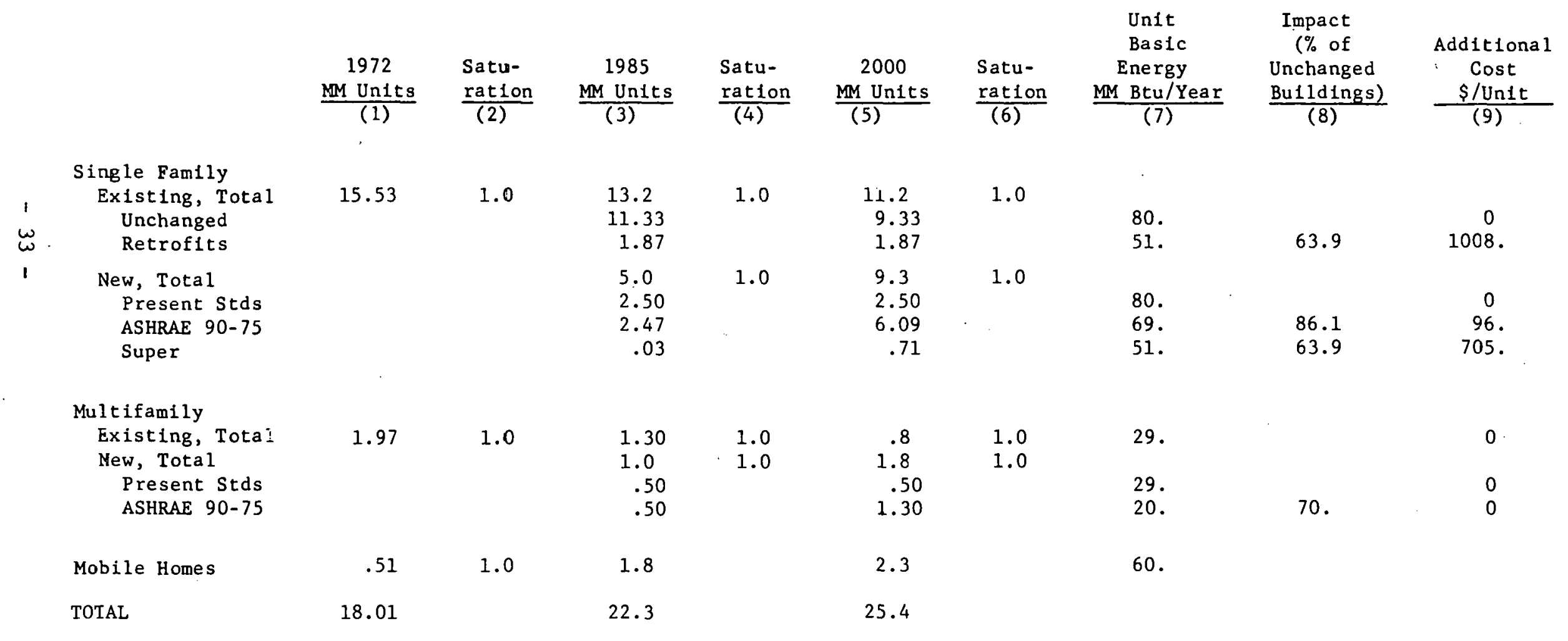


TABLE 5

REGION: SOUTH

DEMAND CATEGORY: SPACE HEAT, FESIDENTIAL

\begin{tabular}{|c|c|c|c|c|c|c|c|c|}
\hline$\frac{1972}{(1)}$ & $\begin{array}{l}\text { Satu- } \\
\text { ration } \\
(2)\end{array}$ & $\begin{array}{c}1985 \\
\frac{\text { MM Untt.s }}{(3)}\end{array}$ & $\begin{array}{l}\text { Satu- } \\
\frac{\text { ration }}{(4)}\end{array}$ & $\begin{array}{c}2000 \\
\frac{\text { MM Units }}{(5)}\end{array}$ & $\begin{array}{l}\text { Satu- } \\
\text { retion } \\
(6)\end{array}$ & $\begin{array}{c}\text { Unit } \\
\text { Basic } \\
\text { Energy } \\
\text { MM Btu/Year } \\
(7)\end{array}$ & $\begin{array}{c}\text { Impact } \\
(\% \text { of } \\
\text { Unchanged } \\
\frac{\text { Bu1ldings) }}{(8)}\end{array}$ & $\begin{array}{c}\text { Additional } \\
\text { Cost } \\
\text { \$/Unit }\end{array}$ \\
\hline \multirow[t]{2}{*}{17.35} & $1 . .0$ & $\begin{array}{r}13.9 \\
11.87 \\
2.03\end{array}$ & 1.0 & $\begin{array}{l}11.8 \\
9.77 \\
2.03\end{array}$ & 1.0 & $\begin{array}{l}35 \\
23\end{array}$ & 64.7 & $\begin{array}{r}0 \\
\$ 1008\end{array}$ \\
\hline & & $\begin{array}{l}8.2 \\
4.10 \\
4.06 \\
.04\end{array}$ & 1.0 & $\begin{array}{c}16.3 \\
4.10 \\
10.98 \\
1.22\end{array}$ & 1.0 & $\begin{array}{l}35 . \\
35 . \\
23 .\end{array}$ & $\begin{array}{r}100 . \\
99.7 \\
64.7\end{array}$ & $\begin{array}{r}0 \\
128 \\
705\end{array}$ \\
\hline
\end{tabular}

Multifamily

Existing, Total

New, Total

Present $S \pm d s$

ASHRAE $90-75$

$\begin{array}{rrrrrr}1.85 & 1.0 & 1.1 & 1.0 & .8 & 1.0 \\ & & 1.6 & 1.0 & 2.8 & 1.0 \\ & & .80 & & .80 & \\ & & & & 2.0 & \\ .91 & 1.0 & 2.8 & 1.0 & 3.7 & 1.0 \\ 20.11 & & 27.6 & & 35.4 & \end{array}$

12.

12.

6.51 .9

0

0

99.

Mobile Homes

20.11

27.6

25.

TOTAL

20


TABLE 6

REGION: WEST

DEMAND CATEGORY: SPACE HEAT, RESIDENTIAL

\begin{tabular}{|c|c|c|c|c|c|c|c|c|c|}
\hline & $\frac{\begin{array}{c}1972 \\
M \text { Units }\end{array}}{(1)}$ & $\begin{array}{l}\text { Sata- } \\
\frac{\text { ration }}{(2 !}\end{array}$ & $\begin{array}{c}1985 \\
\frac{\text { M Units }}{(3)}\end{array}$ & $\begin{array}{l}\text { Satu- } \\
\text { ration } \\
(4)\end{array}$ & $\begin{array}{c}2000 \\
\frac{M \text { Units }}{(5)}\end{array}$ & $\begin{array}{l}\text { Satu- } \\
\frac{\text { ration }}{(6)}\end{array}$ & $\begin{array}{c}\text { Unit } \\
\text { Basic } \\
\text { Energy } \\
\frac{\text { M Btu/Year }}{(7)}\end{array}$ & $\begin{array}{l}\text { Impact } \\
(\% \text { of } \\
\text { Unchanged } \\
\frac{\text { Buildings) }}{(8)}\end{array}$ & $\begin{array}{c}\text { Addit Lona } 1 \\
\text { Cost } \\
\text { \$/Unit } \\
(9)\end{array}$ \\
\hline $\begin{array}{c}\text { Single Family } \\
\text { Existing, Total } \\
\text { Unchanged } \\
\text { Retrofits }\end{array}$ & 9.35 & 1.0 & $\begin{array}{l}6.9 \\
5.84 \\
1.06\end{array}$ & 1.0 & $\begin{array}{l}5.7 \\
4.64 \\
1.06\end{array}$ & 1.0 & $\begin{array}{l}44 . \\
26 .\end{array}$ & 60 & $\begin{array}{r}0 \\
\$ 1008\end{array}$ \\
\hline $\begin{array}{l}\text { New, Total } \\
\text { Present Stds } \\
\text { ASHRAE } 90-75 \\
\text { Super }\end{array}$ & . & & $\begin{array}{l}4.2 \\
2.10 \\
2.08 \\
.02\end{array}$ & 1.0 & $\begin{array}{l}7.8 \\
2.10 \\
5.13 \\
.57\end{array}$ & 1.0 & $\begin{array}{l}44 . \\
44 . \\
26 .\end{array}$ & $\begin{array}{r}100 \\
100 \\
60\end{array}$ & $\begin{array}{r}0 \\
160 \\
705\end{array}$ \\
\hline $\begin{array}{l}\text { Multifamily } \\
\text { Existing, Total } \\
\text { New, Total } \\
\text { Present Stds } \\
\text { ASHRAE } 90-75\end{array}$ & 1.92 & 1.0 & $\begin{array}{l}1.2 \\
1.3 \\
.65 \\
.65\end{array}$ & $\begin{array}{l}1.0 \\
1.0\end{array}$ & $\begin{array}{r}.7 \\
2.3 \\
.65 \\
1.65\end{array}$ & $\begin{array}{l}1.0 \\
1.0\end{array}$ & $\begin{array}{l}16 . \\
16 . \\
8 .\end{array}$ & 51.9 & $\begin{array}{r}0 \\
0 \\
0 \\
54\end{array}$ \\
\hline Mobile Homes & .49 & 1.0 & 1.0 & 1.0 & 1.2 & 1.0 & 30 . & & \\
\hline TOTAL & 11.76 & & 14.6 & & 17.7 & & & & \\
\hline
\end{tabular}


TABLE 7

REGION: NORTHEAST

DEMAND CATEGORY: COOLIWG, RESIDENTIAL

\begin{tabular}{|c|c|c|c|c|c|c|c|c|}
\hline & & & & & & $\begin{array}{l}\text { Un1t } \\
\text { Basic }\end{array}$ & $\begin{array}{r}\text { Impact } \\
(\% \text { of }\end{array}$ & Additiona 1 \\
\hline$\frac{\text { M Un1ts }}{(1)}$ & $\begin{array}{l}\text { Satu- } \\
\frac{\text { rat1on }}{(2)}\end{array}$ & $\frac{1985}{(3)}$ & $\begin{array}{l}\text { Satu- } \\
\frac{\text { ration }}{: 4)}\end{array}$ & $\begin{array}{c}2000 \\
\frac{\text { M Units }}{(\bar{j})}\end{array}$ & $\begin{array}{l}\text { Setu- } \\
\text { ration } \\
\frac{(6)}{6}\end{array}$ & $\begin{array}{c}\begin{array}{c}\text { Energy } \\
\text { MM Btu/Year }\end{array} \\
(7)\end{array}$ & $\begin{array}{l}\text { Unchanged } \\
\text { Bu1ldings) }\end{array}$ & $\begin{array}{c}\text { Cost } \\
\text { S/Unit } \\
(9)\end{array}$ \\
\hline
\end{tabular}

Single Family

Existing. Total

Unchanged

12. 12

.31

10.3

Retrofte

9.31

7.91
1.49

.59

17.4

New, Tata

Present Stds

ASHRAE 90-75

Super

3.7

.37

1.0

13.6

78.

0

1.85

37

1.83

1.85
5.27

1.0

$\begin{array}{ll}1 & 0 \\ 1 & 0\end{array}$

.02

17.4

10.4

10.4

60

0

Multifamily

Existing, Tota 1

3. 54

.31

2.7

1.0

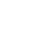

New, Total

Present Stds

ASHRAE 90-75

Mobile Homes

.25

.31

.31

i. 9

3.2

.31

.49

21.

1.0

21.

$\begin{array}{llr}9 & .31 & .9 \\ .9 & 1.0 & 6.3\end{array}$

1.0

10.5

50.

.81

21 .

TOTAL

15.91

19.9

23.2 
TABLE 8

REGION: NORTH CENTRAL

DEMAND CATEGORY: COOLING, RESIDENTIAL

\begin{tabular}{|c|c|c|c|c|c|c|c|c|}
\hline & & & & & & $\begin{array}{l}\text { Unit } \\
\text { Basic }\end{array}$ & $\begin{array}{r}\text { Impact } \\
(\% \text { of }\end{array}$ & Additional \\
\hline $\begin{array}{c}1972 \\
\text { M Units } \\
(1)\end{array}$ & $\begin{array}{l}\text { Satu- } \\
\frac{\text { rat 1on }}{(2)}\end{array}$ & $\begin{array}{c}1985 \\
\text { MM Units } \\
(3)\end{array}$ & $\begin{array}{l}\text { Satu- } \\
\frac{\text { ration }}{(4)}\end{array}$ & $\begin{array}{c}2000 \\
\frac{\text { M Units }}{(5)}\end{array}$ & $\begin{array}{l}\text { Satu- } \\
\text { ration } \\
(6)\end{array}$ & $\begin{array}{c}\begin{array}{c}\text { Energy } \\
\text { M Btu/Year }\end{array} \\
\frac{(7)}{(7)}\end{array}$ & $\begin{array}{l}\text { Unchanged } \\
\text { Buildings) } \\
(8)\end{array}$ & $\begin{array}{c}\text { Cost } \\
\text { S/Un1t }\end{array}$ \\
\hline
\end{tabular}

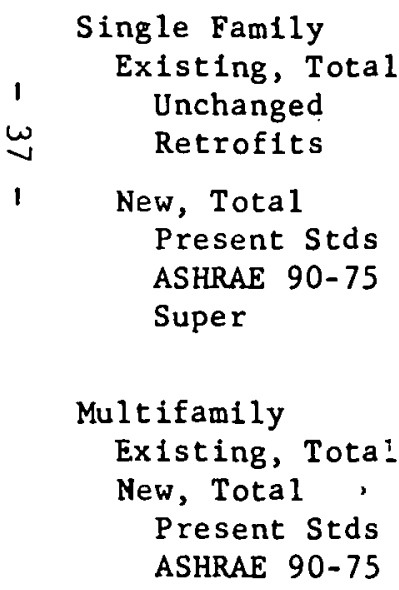

Mobile Homes

TOTAL
.51

.34

15.53

1.97

.34

1. 30

1.0

.50

.36
1.0

1.8

.50

22.3
11.2

9.33

.67

1.0

22 .

9.3

2.50

6.09

1.0

1.0

1.0

.8
1.8

.50

1. 30

2.3

25.4

26.
79.

0

28.

17.4

17.4

62.

62.

26.

26.

10.7

41.

0 
TABLE 9

REGION: SOUTH

DEMAND CATEGORY: COOLING, RESILENT IAL

\begin{tabular}{|c|c|c|c|c|c|c|c|c|c|}
\hline & $\begin{array}{c}19: 2 \\
\text { May Units } \\
(1)\end{array}$ & $\begin{array}{l}\text { Satu- } \\
\frac{\text { ration }}{(2)}\end{array}$ & $\begin{array}{c}1935 \\
\text { MM U.ALs } \\
(3)\end{array}$ & $\begin{array}{l}\text { Satu- } \\
\text { sat1on } \\
(4)\end{array}$ & $\begin{array}{c}2000 \\
\frac{\text { M Units }}{(5)}\end{array}$ & $\begin{array}{l}\text { Satu- } \\
\text { ration } \\
\frac{(6)}{6}\end{array}$ & $\begin{array}{c}\text { Unit } \\
\text { Basic } \\
\text { Energy } \\
\text { M Btu/Year } \\
(7)\end{array}$ & $\begin{array}{c}\text { Impact } \\
(\% \text { of } \\
\text { Unchanged } \\
\text { Bu1ld1ngs) } \\
(8)\end{array}$ & $\begin{array}{c}\text { Additiona } 1 \\
\text { Cost } \\
\text { S/Unit } \\
(9)\end{array}$ \\
\hline $\begin{array}{l}\text { Single Family } \\
\text { Existing, Total }\end{array}$ & $=7.35$ & .52 & 13.9 & & 11.8 & $\mathbb{1} .0$ & 37. & & \\
\hline $\begin{array}{l}\text { Unchanged } \\
\text { Retrofits }\end{array}$ & & & $\begin{array}{r}11.87 \\
2.03\end{array}$ & $\begin{array}{l}.63 \\
.63\end{array}$ & $\begin{array}{l}9.77 \\
2.03\end{array}$ & $\begin{array}{l}1.0 \\
1.0\end{array}$ & 28.5 & 77 & 0 \\
\hline $\begin{array}{l}\text { New, Total } \\
\text { Present Stds } \\
\text { ASHRAE 90-75 } \\
\text { Super }\end{array}$ & & & $\begin{array}{l}3.2 \\
4.10 \\
4.36 \\
.04\end{array}$ & $\begin{array}{l}.63 \\
1.0 \\
1.0\end{array}$ & $\begin{array}{r}16.3 \\
4.10 \\
10.98 \\
1.22\end{array}$ & $\begin{array}{l}1.0 \\
1.0 \\
1.0\end{array}$ & $\begin{array}{l}37 . \\
26 . \\
26 .\end{array}$ & 71. & 0 \\
\hline $\begin{array}{l}\text { Multifamily } \\
\text { Existing, Total } \\
\text { New, Total } \\
\text { Present Stds } \\
\text { ASHRAE } 90-75\end{array}$ & 1.85 & .52 & $\begin{array}{r}1.1 \\
1.6 \\
.80 \\
.80\end{array}$ & $\begin{aligned} & .57 \\
& .57 \\
&-.0\end{aligned}$ & $\begin{array}{r}.8 \\
2.8 \\
.80 \\
2.00\end{array}$ & $\begin{array}{l}1.0 \\
1.0 \\
1.0\end{array}$ & $\begin{array}{l}41 . \\
41 . \\
14.8\end{array}$ & 36 . & : \\
\hline Mobile Homes & .91 & .52 & 2.8 & .70 & 3.7 & 1.00 & 41. & & \\
\hline TOTAL & 20.11 & & 27.6 & & 35.4 & & & & \\
\hline
\end{tabular}


TABLE 10

REGION: WEST

DEMAND CATEGORY: COOLING, RESIDENTIAL

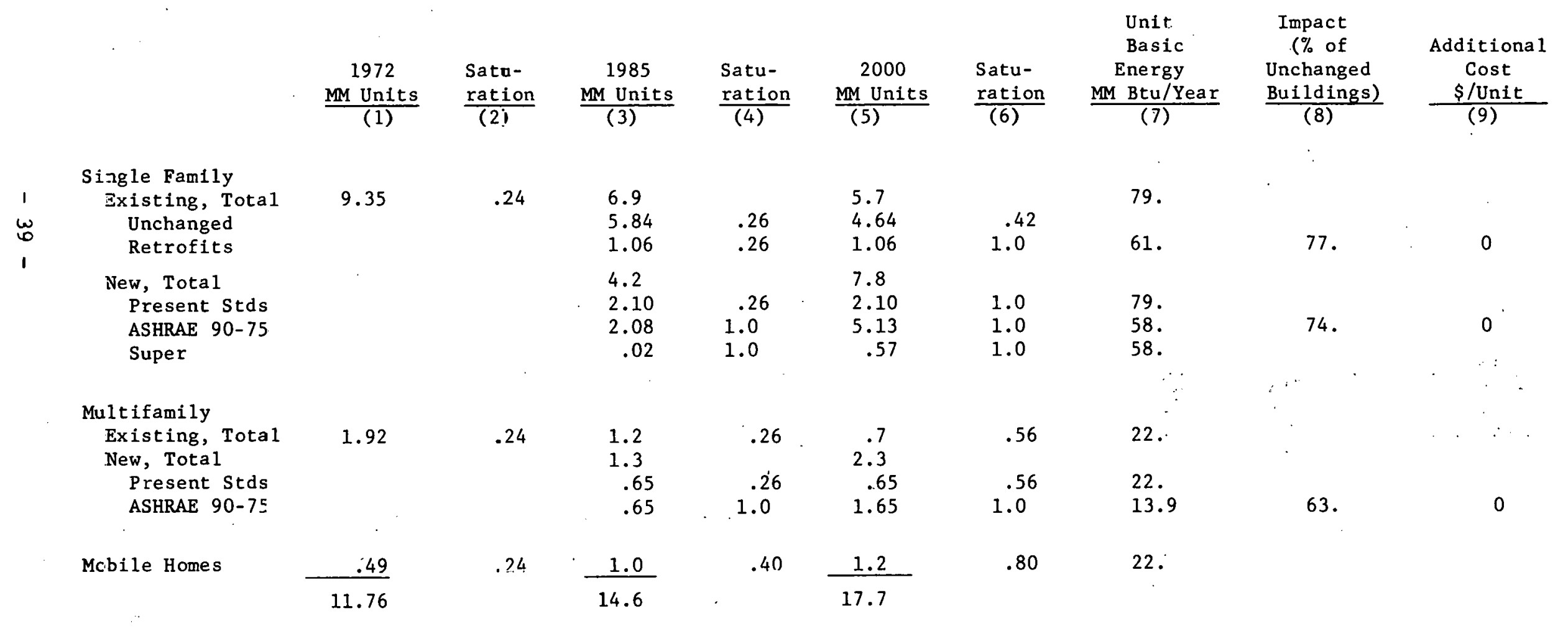


TABLE 11

REGION: U.S.

DEMAND CATEGORY: WATER HEATINE, RESIDENTIAL

\begin{tabular}{|c|c|c|c|c|c|c|c|c|c|}
\hline - & $\begin{array}{c}1972 \\
\text { MM Units } \\
(1 \vdots\end{array}$ & $\begin{array}{l}\text { Satu- } \\
\frac{\text { rat1on }}{(2)}\end{array}$ & $\begin{array}{c}1985 \\
\frac{M \text { Units }}{(3)}\end{array}$ & $\begin{array}{l}\text { Satu- } \\
\frac{\text { ration }}{(4)}\end{array}$ & $\begin{array}{c}2000 \\
\frac{\text { M Units }}{(5)}\end{array}$ & $\begin{array}{l}\text { Satu- } \\
\frac{\text { retion }}{(6)}\end{array}$ & $\begin{array}{c}\text { Unit } \\
\text { Basic } \\
\text { Energy } \\
\text { MM Btu/Year } \\
\frac{(7)}{(7)}\end{array}$ & $\begin{array}{c}\text { Impact } \\
(\% \text { of } \\
\text { Unchanged } \\
\frac{\text { Bu1ldings })}{(8)}\end{array}$ & $\begin{array}{c}\text { Additiona } 1 \\
\text { Cost } \\
\text { S/Unit } \\
(9)\end{array}$ \\
\hline $\begin{array}{l}\text { Single Family } \\
\text { Existing, Total } \\
\text { Unchanged. } \\
\text { Retrofits }\end{array}$ & 54.35 & 1.0 & $\begin{array}{l}4.4 .8 \\
58.35 \\
6.45\end{array}$ & 1.0 & $\begin{array}{r}38.1 \\
31.65 \\
6.45\end{array}$ & i. 0 & $\begin{array}{l}13 . \\
13 .\end{array}$ & . & $\begin{array}{l}0 \\
0\end{array}$ \\
\hline $\begin{array}{l}\text { New, Total } \\
\text { Present Stds } \\
\text { ASHRAE } 90-75 \\
\text { Super }\end{array}$ & & & $\begin{array}{l}21.1 \\
10.55 \\
10.44 \\
.11\end{array}$ & 1.0 & $\begin{array}{r}40.90 \\
10.55 \\
27.47 \\
2.88\end{array}$ & 1.0 & $\begin{array}{r}13 . \\
9 . \\
9 .\end{array}$ & $\begin{array}{l}70 . \\
70 .\end{array}$ & $\begin{array}{r}0 \\
48 \\
48\end{array}$ \\
\hline $\begin{array}{l}\text { Multifamily } \\
\text { Existing, Total } \\
\text { New, Total } \\
\text { Present Stds } \\
\text { ASHRAE } 90-75\end{array}$ & $\Xi 2.3$ & 1.0 & $\begin{array}{l}6.3 \\
5.7 \\
2.85 \\
2.85\end{array}$ & $\begin{array}{l}1.0 \\
1.0\end{array}$ & $\begin{array}{c}4.2 \\
10.1 \\
2.85 \\
7.25\end{array}$ & $\begin{array}{l}1.0 \\
1.0\end{array}$ & $\begin{array}{l}21 . \\
21 . \\
15 .\end{array}$ & 70 & $\begin{array}{r}0 \\
0 \\
72\end{array}$ \\
\hline Mobile Homes & 2.15 & 1.0 & 6.5 & 10. & 8.4 & 1.0 & 13. & & \\
\hline TOTAL & $6 \equiv .79$ & & 84.4 & & 101.7 & & & & \\
\hline
\end{tabular}


TABLE 12

REGIJN: U.S.

DEMAND CATEGORY: IIGHT \& POWER, RESIDINTIAL

\begin{tabular}{|c|c|c|c|c|c|c|c|c|c|}
\hline & $\begin{array}{c}1972 \\
\text { MY Units } \\
(1)\end{array}$ & $\begin{array}{l}\text { Satu- } \\
\text { ration } \\
(2)\end{array}$ & $\begin{array}{c}1985 \\
\frac{\text { M Units }}{(3)}\end{array}$ & $\begin{array}{l}\text { Satu- } \\
\frac{\text { ration }}{(4)}\end{array}$ & $\begin{array}{c}2000 \\
\frac{M \text { Untts }}{(5)}\end{array}$ & $\begin{array}{l}\text { Satu- } \\
\frac{\text { ration }}{(6)}\end{array}$ & $\begin{array}{c}\text { Unit } \\
\text { Basic } \\
\text { Energy } \\
\text { MM Btu/Year } \\
(7)\end{array}$ & $\begin{array}{l}\text { Impact } \\
\text { (\% of } \\
\text { Unchanged } \\
\frac{\text { Bu1ldings) }}{(8)}\end{array}$ & $\begin{array}{c}\text { Additional } \\
\text { Cost } \\
\text { \$/Unit } \\
(9)\end{array}$ \\
\hline $\begin{array}{l}\text { Single Family } \\
\text { Existing, Total } \\
\text { Unchanged } \\
\text { Retrofits }\end{array}$ & 54.35 & .45 & $\begin{array}{l}44.8 \\
38.35 \\
6.45\end{array}$ & $\begin{array}{r}.45 \\
.45\end{array}$ & $\begin{array}{l}38.1 \\
31.65 \\
6.45\end{array}$ & $\begin{array}{l}.59 \\
.59\end{array}$ & $\begin{array}{l}32.8 \\
32.8\end{array}$ & & 0 \\
\hline $\begin{array}{l}\text { New, Total } \\
\text { Present stds } \\
\text { ASHRAE } 90-75 \\
\text { Super }\end{array}$ & & & $\begin{array}{r}21.1 \\
10.55 \\
10.44 \\
.11\end{array}$ & $\begin{array}{l}1.0 \\
1.0 \\
1.0\end{array}$ & $\begin{array}{l}40.9 \\
10.55 \\
27.47 \\
2.88\end{array}$ & $\begin{array}{l}1.0 \\
1.0 \\
1.0\end{array}$ & $\begin{array}{l}32.8 \\
32.8 \\
32.8\end{array}$ & & $\begin{array}{l}0 \\
0 \\
0\end{array}$ \\
\hline $\begin{array}{l}\text { Multifamily } \\
\text { Ezisting, Total } \\
\text { New, Total } \\
\text { Present Stds } \\
\text { ASHRAE } 90-75\end{array}$ & 9.28 &.$\angle 5$ & $\begin{array}{l}6.3 \\
5.7 \\
2.85 \\
2.85\end{array}$ & $\begin{array}{l}.45 \\
.45 \\
1.0\end{array}$ & $\begin{array}{c}4.2 \\
10.1 \\
2.85 \\
7.25\end{array}$ & $\begin{array}{l}.59 \\
.59 \\
1.0\end{array}$ & $\begin{array}{l}25 . \\
25 . \\
17.3\end{array}$ & 69 & 0 \\
\hline Mobile Homes & 2.16 & .45 & 6.5 & .58 & 8.4 & .80 & 25 . & & \\
\hline TOTAL & 65.79 & & 84.4 & & 101.7 & & & & \\
\hline
\end{tabular}


TABLE 13

REGION: U.S.

DEMAND CATEGORY:

SPAC HEAT, DOMERCIAL

\begin{tabular}{|c|c|c|c|c|c|c|c|c|c|}
\hline : & 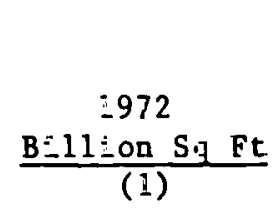 & $\begin{array}{l}\text { Satu- } \\
\frac{\text { ration }}{(2)}\end{array}$ & $\begin{array}{c}1985 \\
\frac{B 1111 \text { on } S q}{(3)}\end{array}$ & $\begin{array}{l}\text { Satu- } \\
\text { ration } \\
(4)\end{array}$ & $\begin{array}{c}2000 \\
\text { B11lion Sq Ft }\end{array}$ & $\begin{array}{l}\text { Satu- } \\
\text { ration }\end{array}$ & $\begin{array}{c}\text { Unit } \\
\text { Basic } \\
\text { Energy } \\
\text { M Btu/Sg Ft } \\
\frac{(7)}{(7)}\end{array}$ & 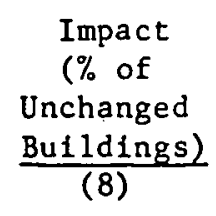 & $\begin{array}{l}\text { Additional } \\
\text { Cost } \\
S / \mathrm{Sg} F t \\
(9)\end{array}$ \\
\hline $\begin{array}{l}\text { Offices, Total } \\
\text { Existing } \\
\text { New, Present Stds } \\
\text { New, ASHRAE 90-75 }\end{array}$ & $3.84 i$ & 1.0 & $\begin{array}{l}6.08 \\
3.11 \\
1.49 \\
1.48\end{array}$ & 1.0 & $\begin{array}{l}9.66 \\
2.66 \\
1.49 \\
5.51\end{array}$ & 1.0 & $\begin{array}{l}74 . \\
74 . \\
20 .\end{array}$ & 27. & .39 \\
\hline $\begin{array}{l}\text { Retail Stores, Total } \\
\text { Existing } \\
\text { New, Present Stds } \\
\text { New, ASHRAE 90-75 }\end{array}$ & $4.88 \equiv$ & 1.0 & $\begin{array}{l}8.0 \\
3.92 \\
2.04 \\
2.04\end{array}$ & 1.0 & $\begin{array}{r}10.08 \\
2.80 \\
2.04 \\
5.24\end{array}$ & 1.0 & $\begin{array}{l}22 . \\
22 . \\
5.7\end{array}$ & 26. & .59 \\
\hline $\begin{array}{l}\text { Schools, Total } \\
\text { Existing } \\
\text { New, Present Stds } \\
\text { New, ASHRAE } 90-75 \\
\end{array}$ & 5.393 & 1.0 & $\begin{array}{r}6.08 \\
4.44 \\
.82 \\
.32\end{array}$ & 1.0 & $\begin{array}{r}6.30 \\
3.35 \\
.82 \\
2.13\end{array}$ & 1.0 & $\begin{array}{l}42 . \\
42 . \\
16 .\end{array}$ & 38. & .52 \\
\hline $\begin{array}{l}\text { Other, Total } \\
\text { Existing } \\
\text { New, Present Stds } \\
\text { New, ASHRAE 90-75 }\end{array}$ & 3.701 & 1.0 & $\begin{array}{r}11.34 \\
7.99 \\
1.93 \\
1.92\end{array}$ & 1.0 & $\begin{array}{r}15.96 \\
6.00 \\
1.92 \\
8.04\end{array}$ & 1.0 & $\begin{array}{l}74 . \\
74 . \\
20 .\end{array}$ & 27. & .39 \\
\hline TOTAL & 23.818 & & 32.00 & & 42.00 & & & & \\
\hline
\end{tabular}


TABLE 14

REGION: U.S.

DEMAND CATEGORY: AIR CONDITIONING, COMMERCIAL

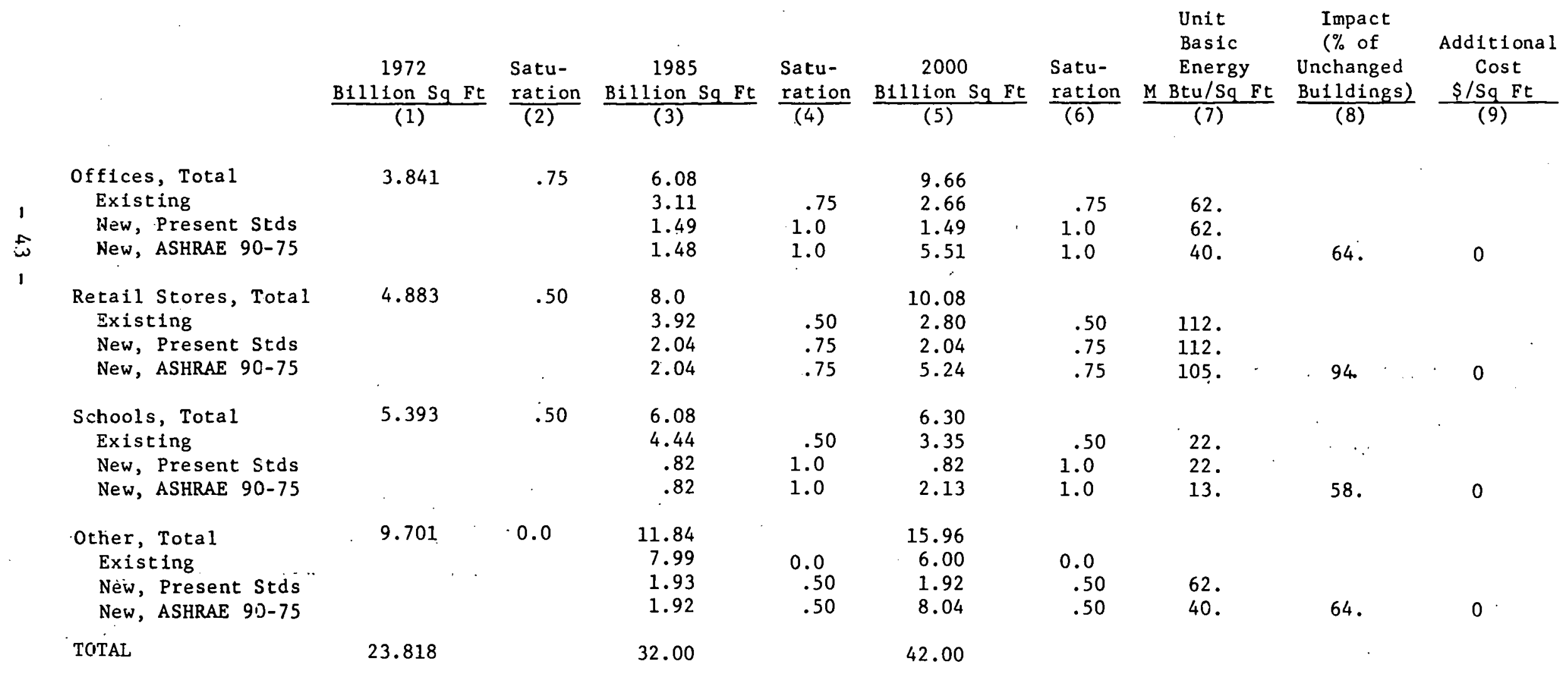


TABLE 15

REGION: U.S

DEMAND CATEGORY: HVAC AUYILIARIES, COMMERCIAL

\begin{tabular}{|c|c|c|c|c|c|c|c|c|c|}
\hline . & $\frac{1972}{\text { Etllian } 5 \mathrm{~g} F E}$ & $\begin{array}{l}\text { Satu- } \\
\text { ration } \\
\frac{(2)}{}\end{array}$ & $\begin{array}{c}1.985 \\
\text { Billi.on Sq Ft }\end{array}$ & $\begin{array}{l}\text { Satu- } \\
\text { ration } \\
(4)\end{array}$ & $\begin{array}{c}2000 \\
\text { B11lion Sq Ft } \\
(5)\end{array}$ & $\begin{array}{l}\text { Satu- } \\
\text { ration } \\
(6)\end{array}$ & $\begin{array}{c}\text { Unit } \\
\text { Basic } \\
\text { Energy } \\
\text { M Btu/Sg Ft } \\
\frac{(7)}{7)}\end{array}$ & $\begin{array}{l}\begin{array}{l}\text { Impact } \\
(\% \text { of } \\
\text { Unchanged } \\
\text { Bu1ldings) }\end{array} \\
\frac{(8)}{(8)}\end{array}$ & $\begin{array}{l}\text { Additional } \\
\text { Cost } \\
S / \text { Sg Ft } \\
(9)\end{array}$ \\
\hline $\begin{array}{l}\text { Offices, Total } \\
\text { Existing } \\
\text { New, Present Stds } \\
\text { New, ASHRAE 90-75 }\end{array}$ & 3.841 & .75 & $\begin{array}{l}6.08 \\
3.11 \\
1.49 \\
1.48\end{array}$ & $\begin{array}{l}.75 \\
1.0 \\
1.0\end{array}$ & $\begin{array}{l}9.66 \\
2.66 \\
1.49 \\
5.51\end{array}$ & $\begin{array}{l}.75 \\
1.0 \\
1.0\end{array}$ & $\begin{array}{r}26 . \\
26 . \\
9 .\end{array}$ & 36. & 0 \\
\hline $\begin{array}{l}\text { Retail Stores, Total } \\
\text { Existing } \\
\text { New, Present Stds } \\
\text { New, ASHRAE } 90-75\end{array}$ & 4.883 & .50 & $\begin{array}{l}8.0 \\
3.92 \\
2.04 \\
2.04\end{array}$ & $\begin{array}{l}.50 \\
.75 \\
.75\end{array}$ & $\begin{array}{r}10.08 \\
2.80 \\
2.04 \\
5.24\end{array}$ & $\begin{array}{l}.50 \\
.75 \\
.75\end{array}$ & $\begin{array}{r}106 . \\
106 . \\
61 .\end{array}$ & 58. & 0 \\
\hline $\begin{array}{l}\text { Schools, Total } \\
\text { Existing } \\
\text { New, Present Stds } \\
\text { New, ASHRAE } 90-75\end{array}$ & 5.393 & .50 & $\begin{array}{r}6.08 \\
4.44 \\
.82 \\
.82\end{array}$ & $\begin{array}{l}.50 \\
1.0 \\
1.0\end{array}$ & $\begin{array}{r}6.30 \\
3.35 \\
.82 \\
2.13\end{array}$ & $\begin{array}{l}.50 \\
1.0 \\
1.0\end{array}$ & $\begin{array}{l}6 . \\
6 . \\
3 .\end{array}$ & 53. & 0 \\
\hline $\begin{array}{l}\text { Other, Total } \\
\text { Existing } \\
\text { New, Present Stds } \\
\text { New, ASHRAE 90-75 }\end{array}$ & 9.701 & 0.0 & $\begin{array}{r}11.84 \\
7.99 \\
1.93 \\
1.92\end{array}$ & $\begin{array}{l}0.0 \\
.50 \\
.50\end{array}$ & $\begin{array}{r}15.96 \\
6.00 \\
1.92 \\
8.04\end{array}$ & $\begin{array}{l}0.0 \\
.50 \\
.50\end{array}$ & $\begin{array}{l}26 . \\
26 . \\
9 .\end{array}$ & 36. & 0 \\
\hline TOTAL & 23.818 & & 32.30 & & 42.00 & & & & \\
\hline
\end{tabular}


TARLE 16

REGION: U.S.

DEMAND CATEGORY: LIGHT AND POWER, COMMERCIAL

\begin{tabular}{|c|c|c|c|c|c|c|c|c|c|}
\hline & $\begin{array}{c}1972 \\
\text { B111ion Sq Ft }\end{array}$ & $\begin{array}{l}\text { Satu- } \\
\text { ration } \\
(2)\end{array}$ & $\begin{array}{c}1985 \\
\text { B1111on Sq Ft }\end{array}$ & $\begin{array}{l}\text { Satu- } \\
\text { ration } \\
(4)\end{array}$ & $\begin{array}{c}2000 \\
\text { Billion Sq Ft } \\
(5)\end{array}$ & $\begin{array}{l}\text { Satu- } \\
\text { ration } \\
(6)\end{array}$ & $\begin{array}{l}\text { Unit } \\
\text { Basic } \\
\text { Energy } \\
\mathrm{M} \mathrm{Btu/Sg \quad Ft} \\
\frac{(7)}{}\end{array}$ & $\begin{array}{l}\text { Impact } \\
(\% \text { of } \\
\text { Unchanged } \\
\frac{\text { Buildings })}{(8)}\end{array}$ & $\begin{array}{l}\text { Additional } \\
\text { Cost } \\
\frac{S / \mathrm{Sq} F t}{(9)}\end{array}$ \\
\hline $\begin{array}{l}\text { Offices, Total } \\
\text { Existing } \\
\text { New, Present Stds } \\
\text { New, ASHRAE 90-75 }\end{array}$ & 3.841 & .75 & $\begin{array}{l}6.08 \\
3.11 \\
1.49 \\
1.48\end{array}$ & $\begin{array}{l}.75 \\
.75 \\
.75\end{array}$ & $\begin{array}{l}9.66 \\
2.66 \\
1.49 \\
5 . .51\end{array}$ & $\begin{array}{l}.75 \\
.75 \\
.75\end{array}$ & $\begin{array}{l}54 . \\
54 . \\
38 .\end{array}$ & 71. & 0 \\
\hline $\begin{array}{l}\text { Retail Stores, Total } \\
\text { Existing } \\
\text { Уew, Present Stds } \\
\text { Mew, ASHRAE 90-75 }\end{array}$ & 4.883 & .75 & $\begin{array}{l}8.0 \\
3.92 \\
2.04 \\
2.04\end{array}$ & $\begin{array}{l}.75 \\
.75 \\
.75\end{array}$ & $\begin{array}{r}10.08 \\
2.80 \\
2.04 \\
5.24\end{array}$ & $\begin{array}{l}.75 \\
.75 \\
.75\end{array}$ & $\begin{array}{l}89 . \\
89 . \\
61 .\end{array}$ & 69. & 0 \\
\hline $\begin{array}{l}\text { Schools, Total } \\
\text { Existing } \\
\text { Wew, Present Stds } \\
\text { New, ASHRAE } 90-75\end{array}$ & 5.393 & .75 & $\begin{array}{r}6.08 \\
4.44 \\
.82 \\
.82\end{array}$ & $\begin{array}{l}.75 \\
.75 \\
.75\end{array}$ & $\begin{array}{r}6.30 \\
3.35 \\
.82 \\
2.13\end{array}$ & $\begin{array}{l}.75 \\
.75 \\
.75\end{array}$ & $\begin{array}{l}34 . \\
34 . \\
27 .\end{array}$ & 80. & 0 \\
\hline $\begin{array}{l}\text { Other, Total } \\
\text { Existing } \\
\text { New, Present Stds } \\
\text { New, ASHRAE } 90-75\end{array}$ & 9.701 & .50 & $\begin{array}{r}11.84 \\
7.99 \\
1.93 \\
1.92\end{array}$ & $\begin{array}{l}.50 \\
.50 \\
.50\end{array}$ & $\begin{array}{r}15.96 \\
6.00 \\
1.92 \\
8.04\end{array}$ & $\begin{array}{l}.50 \\
.50 \\
.50\end{array}$ & $\begin{array}{l}54 . \\
54 . \\
38 .\end{array}$ & 71. & 0 \\
\hline TOTAL & 23.818 & & 32.00 & & 42.00 & & & & \\
\hline
\end{tabular}


TABLE 17

REGION: U.S.

DEMAND CATEGORY: WATES HEATING, COMMERCIAL

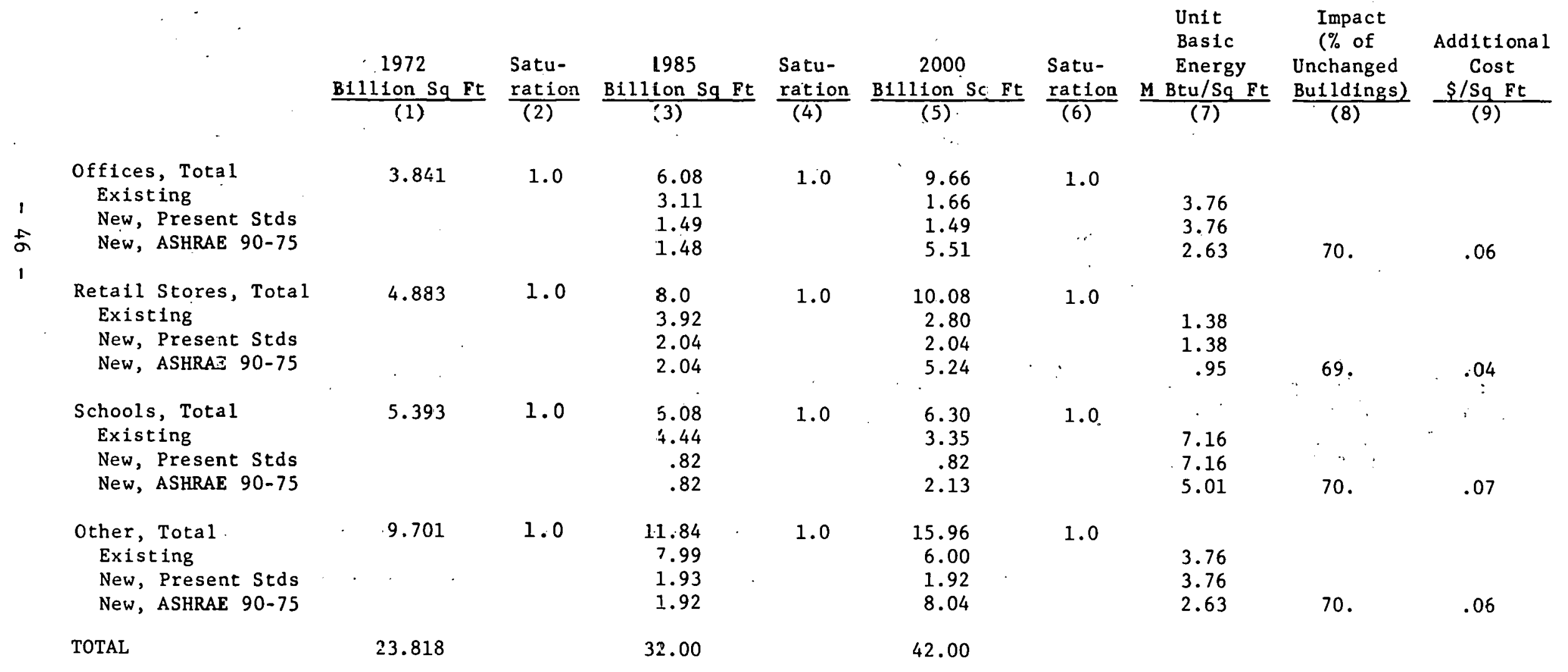


building types and regions. These decreases are tabulated in column 8 of Tables 3-17, expressed as a percentage of the en-: ergy demand of a conventional building. A detailed description of the ASHRAE 90-75 building design specifications is contained in pages 29-34 of (1), with a description of conventional design included for comparison.

The decrease in unit basic energy demand for retrofitted single family units was obtained for space heating and cooling from one of several existing computer programs (in this case, an example of the American Gas Association's E-Cube code presented in (5)) that computes heating and cooling requirements of an average sized unit with small amounts of insulation (walls $17 / 8 "$, ceiling $31 / 2 "$ ) and no storm doors or windows, and the same unit retrofitted (walls $23 / 4$ ", ceiling 6", storm doors and windows) for several cities in the United states. New York, Minneapolis, Birmingham, and Los Angeles were selected as representative of the four regions: in the study.

The cutback in energy requirements turns out to be larger for these retrofitted homes than for the ASHRAE 90-75 designed units. For this reason, the new single family homes that are given "super" standards are considered to have fuel requirements similar to those of retrofitted homes.

For commercial buildings, no retrofitting was incorporated. Data availability is a large problem in this sector; the un- . classified inventory and referred to as "other" commercial space was given fuel demands corresponding to office buildings.

\section{A.3 Saturations}

The unit energy demands for each activity are obtained from the protypical buildings selected in (1) that contain a complete 
array of energy consuming devices. It is clear that the entire building stock is not furnished with the whole set of appliances considered in the prototypes and in order to obtain the total demand (i.e., unit energy demands times number of units), the level of penetration of these devices has to be made explicit. These are shown in columes 2, 4, and 6 in Tables 3-17 for 1972, 1985, and 2000. These saturations are used not only to describe the situation where a home may or may not contain a given appliance, as in the case of air conditioning, but also to calibrate the unit energy demands used, which are based on better-than-average new housing.

Space heaters and water heaters were assumed to be present in all buildings; new construction in the residential. sector was assumed 100 percent saturated for all appliances. Air conditioning saturations using a 1972 base were allowed to increase so that regional averages became consistent with projections in (4). Light and power in the residential sector uses a calculated saturation for 1972 from (2) and for the projections assumes no growth for existing units until 1985, but thereafter does an increase so that the average for the total inventory reaches $80 \%$ by 2000 . The growth in average consumption for miscellaneous electricity is related to increases in income. For the commercial sector there are no puhlished statistics on appliance saturations. Space and water heating were taken as 100 percent and the saturation levels in the other categories (HVAC auxiliary equipment was given the same saturation as air conditioning) were used to calibrate the total demand for electricity with the projections in (2) and (3). 
B. Comparison of Baseline Energy Demands with Other Projections

The data compiled on housing types, unit energy demands and saturations yield two. sets of total basic energy demands for each activity. First, a "baseline demand" is obtained by using the unit energy requirements of existing, unchanged units (by type and region) for the entire stock in each reference year, adjusted by the proper saturations. The second set of demands is obtained by using the appropriate reduced energy demands and their respective implementation levels (and saturation) to obtain a "conservation demand".

A comparison between the baseline demands obtained here and projections made in the Sourcebook for Energy Assessment and the Regional Reference Energy Systems ${ }^{(3)}$ is summarized in Table 18. A perfect match was not expected in view of the different methodologies employed, although a consistency in total housing stock is maintained with the Sourcebook and an even closer correlation of housing stocks (totals, regional breakdown, single to multifamily shares) is kept with the Regional RES projections. The main differences are:

- Commercial Space Heat: the base year. (1972) figure has been obtained in previous projections as a difference between allocated fuels and control totals provided by the Bureau of Mines (fuels to the Household and Commercial Sector). This category, though, includes all uses not classified elsewhere in the other three major Bureau of Mines energy sectors, and it includes a variety of minor energy consumers (constructiun, parls of agriculture). The baseline in this study, on 
the other hand, is obtained strictly from energy demands in buildings. The difference is explained by the slightly overstated amount in the historic base, which are amplified in the projections. It is worthwhile to point out, however, that the fuel consumption of these small users is small; sketchy data on uses in agriculture are available.

- Commercial Air Conditioning: there are no published data on saturation levels for cooling of commercial floor space and the discrepancy between (2) and (3) is largely due to differences in their 1972 base year.' The saturations in this study were adjusted to make the total demand agree with (2). The amounts involved in terms of resources, however, are quite small; the amounts in Table 18 are magnified by an end use efficiency of 3.0 .

- water Heating: the demands derived for this study correspond strictly to energy requircments for water heating, while the other two projections also include cooking in this category.

- Commercial Light and Power: the consumption by auxiliaries to HVIC cquipment (ehilled water, cooling tower fans, toilet exhaust fans, condenser pumpo, humidifisation syuipuent and fans) is tabulated for the three building types in (1). These power demands are added to the usage by lighting and appliances to constitute this demand 
Table 18: Basic Energy Demands, Residential and Commercial Sectors, $10^{15}$ Btu

$\begin{array}{ccc}1972^{1} & \begin{array}{c}\text { ig85 } \\ \text { Source- Regional } \\ \text { book }^{1}\end{array} & \begin{array}{c}2000 \\ \text { RES }^{2}\end{array} \\ & \text { Baseline Baseline } & \begin{array}{c}\text { Source- Regional } \\ \text { book }^{1}\end{array}\end{array}$

Space Heat

$\begin{array}{llllllll}\text { Residential } & 3.31 & 4.12 & 3.60 & 4.12 & 4.19 & 4.20 & 4.93 \\ \text { Commercial } & 1.62 & 1.76 & 2.77 & 3.07 & 2.38 & 3.63 & 3.76 \\ \text { Total } & 4.93 & 5.88 & 6.37 & 7.19 & 7.29 & 7.83 & 8.69\end{array}$

Air Conditioning

$\begin{array}{lrrrrrrr}\text { Residential } & .84 & 1.59 & 1.82 & 1.55 & 3.21 & 3.12 & 2.99 \\ \text { Commercial } & .51 & 1.10 & .96 & 1.63 & 1.74 & 1.70 & 2.76 \\ \text { Total } & 1.35 & 2.69 & 2.78 & 3.18 & 4.95 & 4.82 & 5.75\end{array}$

Water Heat ${ }^{3}$ and

Cooking

Residential

Commercial

$.93 \quad 1.18$

1.84

.57

.12

2.41

1.78

.24

1.44

2.28

2.35

1.03

1.30

2.02

1.60

.76

.32

3.04

2.67

Light and Power

Residential

Commercial

.93
1.23

1.61

1.61

2.00

1.17

1.40

2.53

2.64

1.56

4.20

1.96

3.61

$\begin{array}{ll}1.17 & 1.52 \\ 2.78 & 3.36\end{array}$

2.77
5.30

1.86

2.16

3.82

1. Sourcebook for Energy Assessment (see Ref. 2)

2. Regional Reference Energy Systems (see Ref. 3)

3. Baseline projections are only for water heat 
category. The saturation levels for HVAC auxiliary equipment are determined by those of air conditioners, and this equipment's power demand has a large impact, reaching some $40 \%$ of the total demand in this category by 2000. Neither previous projection (in (2) and (3)) accounted explicitly for auxiliary HVAC equipment and this explains the large differences shown in Table 18.

C. Cost Inputs

The energy savings described above are realized through the outlay of additional expenditures in new construction and retrofitting costs. Only these additional costs over conventional construction (or buildings that remain unchanged) are of concern to BESOM because the version used in the analysis does not include the cost of end use devices.

The estimated unit costs, in 1975 dollars per square foot of floor area, are given for all ASHRAE 90-75 modified and for conventional buildings in A. D. Little's assessment (1), page 77. For each housing type (single family, multifamily, mobile home, office, retail, schools) and region the cost differences were computed for cases where ASHRAE 90-75 proves more expensive than conventional buildings. In the cases where the improved buildings prove less expensive (such as HVAC equipment because smaller units are installed), the cost difference was considered zero. This point is a reflection of the conservative bias in this assessment. 
The following list describes how the different construction elements were allocated among the demand categories.

Space heat: exterior walls

glass

roof

floor insulation

Air Conditioning: HVAC equipment

HVAC distribution

HVAC controls

Water heating: domestic water heat equipment water distribution and fixtures

Lighting and appliances: lighting

electric distribution

In order to achieve consistency with the housing stock data, costs per square foot for the residential sector were converted to costs per unit using 1600 square feet/unit for single family and 900 square feet/unit for multifamily homes. In the commercial sector, data on stocks is consistent with costs per square foot data. Table 19 summarized these incremental costs between ASHRAE 90-75 and conventional homes.

In the case of retrofits there is a vast literature on costs and these fall within a fair sized range. Costs selected for this study include installation by a contractor for a single family house that has 1200 square feet of floor space and 840 square feet of wall area (average pre 1972 construction is assumed to have a floor area $25 \%$ smaller than average new construction). 
Table 19: Incremental costs, ASHRAE 90-75 versus Conventional Buildings (1)

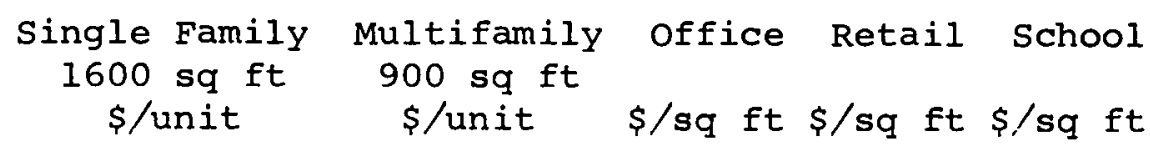

Space Heat

Northeast

Northcentral

176

Suuth

96

West

128

160

$*$
$*$
99
54

.64

.58

.83

.43

.72

.42

.62

.51

Air Conditioning

Northcast'

Northcentral

South

West

Water Heat

48

$*$
$*$
$\star$

.07

.47

.67

Light and Power

0.0

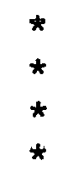

72

0.0

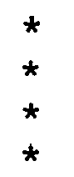

*

$\star$

$\star$

*

. ก6 $\quad .04$

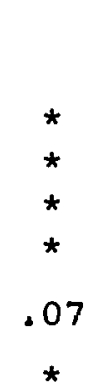

*ASHKAE 9U-75 proves more economical than conventional buildings 1) Source: A. D. Little (Ref. 1). 
Ceiling: 6 inches (R-19) mineral fiber batt at $1 \% / R-s q$ ft

Walls: $23 / 4$ inches blown in at $50 \% /$ sq $\mathrm{ft} \quad 420$

Storm Windows: 7 units at $\$ 30$ each 210

Storm Doors: 2 units at $\$ 75$ each 150

$\$ 1008$

These costs were derived from several sources, $(6,7,8)$. The homes built with "super" standards were given an incremental cost over conventional new construction equivalent to $70 \%$ of the cost of the retrofit described above. This is a rule of thumb to account for the lower installation costs.

D. Extension to BESOM

The Brookhaven Energy System Optimization Model (BESOM)

has been extended to analyze the effect of the decreased energy demands and increased costs of the building design options described here. The model provides changes in total resources, total annualized system costs, changes in capital cost, and environmental effects from decreased energy production. It was primarily designed to accommodate assessments of the range of technological options available in the fields of resource conversions and new resources. Demand activities, however, are entered into the model as single inputs in quadrillion Btu and therefore a straightforward extension was built into BESOM to incorporate explicitly the information on building stocks, unit energy demands, saturations and costs.

The demand activities (right hand sides in the linear program) for the residential and commercial sectors (space heat, water heat, air conditioning, and miscellaneous electricity) are replaced by expressions 


$$
\sum_{I} Y(I) S(I, J) U(I, J)
$$

where $I=1,48$ correspond to the building types and $\mathrm{J}=1,4$ correspond to the demand activities (space heat, air conditioning, etc.)

$$
\begin{aligned}
& \mathrm{Y}(\mathrm{I})=\text { stocks of residential and commercial space } \\
& \mathrm{U}(\mathrm{I}, \mathrm{J})=\text { unit energy demands for each building type and } \\
& \text { each demand } \\
& S(I, J)=\text { saturations. }
\end{aligned}
$$

The above summation represents the basic energy demand for each demand category and thus drives the model in the usual fashion. The building stocks $Y(I)$ are modeled as variables in the linear program and have costs $D(I, J)$ associated to them. These costs are incorporated into the optimization function of the linear program as an additional term

$$
\sum_{J} \sum_{I} D(I, J) S(I, J) Y(I)
$$

The mathematical formulation of BESOM is now

$$
\text { minimize } \sum_{k=1} C(K) x(K)+\sum_{J} \sum_{D(I, J) S(I, J) Y(I)}
$$

subject to

$$
\sum_{K} d(V, K) \times(K)-\sum_{I} Y(I) S(I, J) U(I, J)=0
$$

for the demands in the residential and commercial sector. All other constraints remain unchanged.

In addition, the building stocks are entered as

$$
Y(I)=N_{I}
$$


as a first step, as opposed to allowing the model to choose the least cost housing configuration. The latter option was discarded because unless closely constrained, the outcome could easily prove unrealistic. There is only limited flexibility for breakdowns of building stocks among regions, or among single family and multifamily or pre 1972 construction and new. The values of the vector $\mathrm{N}_{\mathrm{I}}$ can easily be modified to suit varying implementation rates for retrofits and ASHRAE 90-75 standard units, as well as changes in new construction estimates or demolition rates.

E. Analysis of the BESOM Runs

The impact of the improved building design on the total energy demand is summarized in Table 20. This set of basic energy demands for the "baseline" and "conservation" cases are based on the construction and demolition schedules and assumptions on retrofit that went into Tables 3 through 17 . It can be seen that in spite of conservative assumptions on implementation of conservation technologies, important savings of $17 \%$ in space heat and $17 \%$ in light and power are realized. The smaller uses show decreases of $16 \%$ for air conditioning and. $13 \%$ for water heating. It is noteworthy that these cutbacks are produced exclusively by the implementation of better thermal design in new buildings and limited retrofit of existing homes. The assessment excludes all reductions achieved through modified usage, usually referred to as energy management (such as nighttime thermostat setbacks or turning out lights in empty rooms), or reductions in demand as a response to higher prices.* Moreover, because the reductions are expressed in

*These factors are obviously not unrelated, i.e., energy management, improved building designs and retrofits are certainly responsive to higher prices. 
Baseline versus Conservation, Residential and Commercial Buildings

\begin{tabular}{|c|c|c|c|}
\hline & \multicolumn{3}{|c|}{ YEAR 2000, $10^{15}$ BtU BASIC ENERGY } \\
\hline$\because$ & Baseline & Conservation * & Savings \% \\
\hline $\begin{array}{c}\text { Space Heat, Residential } \\
\text { Space Heat, Commercial } \\
\text { TOTAL }\end{array}$ & $\begin{array}{l}4.91 \\
\frac{2.38}{7.29}\end{array}$ & $\begin{array}{l}4.54 \\
1.51 \\
6.05\end{array}$ & $\frac{37}{17}$ \\
\hline $\begin{array}{c}\text { Airconditioning, Residential } \\
\text { Airconditioning, Commercial } \\
\text { TOTAL }\end{array}$ & $\begin{array}{l}3.21 \\
1.74 \\
4.95\end{array}$ & $\begin{array}{l}2.68 \\
\frac{1.48}{4.16}\end{array}$ & $\begin{array}{l}17 \\
\frac{15}{16}\end{array}$ \\
\hline $\begin{array}{c}\text { Water Heat, Residential } \\
\text { water Heat, Commercial } \\
\text { TOTAL }\end{array}$ & $\begin{array}{r}1.44 \\
.16 \\
1.60\end{array}$ & $\begin{array}{r}1.27 \\
.13 \\
1.40\end{array}$ & $\begin{array}{l}12 . \\
\frac{19}{13}\end{array}$ \\
\hline $\begin{array}{l}\text { Light and Power, Residential } \\
\text { Light and Power, Commercial } \\
\text { TOTAL }\end{array}$ & $\begin{array}{l}2.53 \\
2.77 \\
5.30\end{array}$ & $\begin{array}{l}2.23 \\
\frac{2.18}{4.41}\end{array}$ & $\begin{array}{l}12 . \\
\frac{21}{17}\end{array}$ \\
\hline
\end{tabular}

*Demand levels for Conservation I, Conservation II, and Revised Growth Cases. 
basic energy demand, the fuel savings associated with improved conversion technologies, such as the heat pump, are not included. It is felt that price related energy reductions are best obtained from econometric models and the savings from improved conversion devices are extensively treated elsewhere. Lastly the replacement of fossil fuels for heating and cooling by solar energy, often included as an energy conservation option, has also been left out of the analysis. While solar will probably have a slight effect on the demands by the year 2000, the other factors presented here can significantly increase the percentage reductions in Table 20 .

The "baseline" and "conservation" basic energy demands were entered into the optimization model that had as inputs in the other consumption sectors (industry and transportation) the demands shown in Figure 2. The "baseline" run for the year 2000 yields a total resource use of 160 quad and the "conservation" run lowers it $4.4 \%$ to 153 quad. The total system cost also falls $4.0 \%$, i.e., while the conservation package costs the system $\$ 3.84$ billion, the fuels and electric capacity savings are larger, yielding a net cost decrease of $\$ 21.3$ billion for an assumed oil price ( $\$ 1975)$ of $\$ 23 \% \mathrm{bbl}$ and $\$ 18.7$ billion for an assumed oil price of $\$ 16.50 / \mathrm{bbl}$.

The marginal values associated with the building stocks variables in the model indicate the degree of desirability for introduction of more units of a particular type in the model. The difference between the marginal values of two variables yields the amount by which the input cost of the unit represented by the variable with the larger marginal value can increase while remaining preferable to the alternate type of unit. 
Table 21 summarizes these results for two oil prices (\$16.50 and $\$ 23.00)$ for the year 2000 run, in which "retrofits" are compared with "unchanged" units (i.e.. the amount by which costs of "retrofits" can be increased and still be cost effective or indifferent to "unchanged" units), and new ASHRAE 90-75 designed buildings compared with "present standards" conventional construction. "Super" designed units are also evaluated against "present standards." The values are adjusted to represent total investment although the model output deals with annualized costs.

The results (Table 21) show that there is in general a. benefit to be obtained from increased stocks of improved design buildings and retrofits. This is not surprising in view of the overall four percent decrease in resources and total costs. The doliar amounts involved, though, are in most cases in the order of, or larger than, the original cost input, indicating that the extra cost of these improvements are easily offset by the energy savings at the oil prices cited.

For several housing types, the dollar value in Table 21 is rendered less meaningful due to the effect of saturation in the demand for air conditioning. The average air conditioning saturation of the "retrofitted" stock is much larger than that of the "unchanged" stosk making the unit domand appear larger to the model, offsetting the real decrease in unit energy demand due to the retrofit. This is the case for the Northeast, Northcentral, and particularly the West for oingle family "retrofit" versus "unchanged" and also in multifamily West (see Tables 3 to 17). This saturation distortion explains the comparativcly lower and even leydtive values in Table 21 
Marginal Value Analysis: Cost-Effective Additional

$\$ 16.50$ Oil

Retrofit versus Unchanged, \$/unit

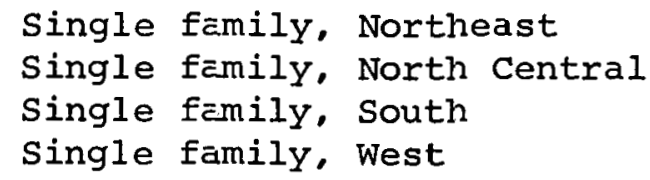

ASHRAE-G0-75 versus Conventional stds., \$/unit

single family, Northeast

Single family, North Central

Single family, South

single family, west

"Super" stds. versus conventional stds.. \$/unit

Sing-e family, Northeast

Singie family, North Eentral

Singie family, South

single family, west

ASHRAE 90-75 versus Conventional stds.. \$/unit

Multifamily, Northeast

Multifamily, North Central

Multifamily, South

Multifamily, West

ASHRAE $90-75$ versus Conventional stds., $\$ /$ sq. ft. Offices

Retail

School
$\$ 23.00$ Oil Cost Input

negative
340
negative
negative

373
846
20

1008

1008

1008

negative

1008

\section{0}

880

313

613

680

993

233

467

224

144

.176

208

700

1173

333

973

973

1586

460

1127

753

753

753

753

1040

900

1013

227

1213

940

933

373

72

72

171

126
4.9
4.0
1.6

5.7

4.3

.45 
for these building stocks. Their larger saturations make the total air conditioning demand of the more efficient homes larger than that of the old stocks it is compared with. In all other categories, however, the saturations of the building types being compared are equal, thereby making the dollar amount of the marginal analysis meaningful.

For a few building types the cost-effective additional expenditures are smaller for the $\$ 23$ per barrel oil than for the $\$ 16.50$ per barrel (Table 21). This counterintuitive result is caused by the seasonal electric space heat and air conditioning balances built into BESOM. The higher price of oil drives the model to prefer more electric heating, causing the marginal value of air conditioning to drop. The decrease in this value between the low oil price and high oil price case is $20 \%$. In the South and West where air conditioning plays a larger role than in the other regions, this feature of the model explains the smaller desirability of ASHRAE 90-75 standards in the $\$ 23$ per barrel case relative to the $\$ 16.50$ per harrel case. 
II-2. INDUSTRIAL BY-PRODUCT ELECTRIC GENERATION

Industrial cogeneration of electricity and heat consists of making use of the available high flame temperature of fuel combustion by first converting the higher temperature heat to electricity in a topping cycle and then utilizing the resultant lower temperature heat in process steam or direct process heat applications. The overall efficiency of the joint generation is much higher than separate central electric and on site steam and heat generation. The potential for implementation is very large because over $40 \%$ of the process steam requirements in the U.S. fall within the range of pressure, capacity and temperature feasible with cogeneration schemes. The technology is not new and is actually in use in the U.S., albeit on a very limited basis, and is used substantially in other countries. Fully 5\% of Sweden's electricity is produced in incustrial back-pressure turbines and $10 \%$ is cogenerated in West Germany (where industry and mining concerns generate nearIy one third of the total electricity).

The interest in cogeneration as an energy saving option has stimulated a number of studies $(12,13,14)$ on the subject, all underscoring the fuel savings and excellent economics of these systems, while pointing out the institutional barriers to speedy implementation. The latter are, briefly, the prohibitively high rates that presently exist for back-up electricity from utilities and the reluctance by utilities to purchase the surplus electricity because they do no control the qualtity. of the sendout and have no desire to become directly involved in decentralized generation. Most importantly, there is the problem of industry's decision to make the investment in cogeneration 
facilities, however attractive the life cycle cost appears to be.

There are several alternative cogeneration systems, each characterized by fuel type, capital cost and efficiency. The most important are:

- Gas turbine topping: fired by oil or gas, it has low capital cost $(\$ 170 / \mathrm{kW}$ at $60 \mathrm{MW}(\mathrm{e})$ and up to $\$ 270 / \mathrm{kW}$ at $10 \mathrm{MW}(\mathrm{e}), \$ 1975$, for new plants $\$ 230 / \mathrm{and} \$ 360 / \mathrm{kW}$ for an existing plant). The additional fuel required to produce electricity, beyond what is needed to make steam alone, is $5500 \mathrm{Btu} /$ $\mathrm{kWh}$. This efficiency (62\% in this case) is referred to as Fuel Chargeable to Power (FCP) and is the conventional manner of rating all byproduct electricity generation systems. The other parameter of importance is the power-to-steam ratio, which is the quantity of electric power that can be generated per unit of process steam. For gas turbines this amount is high, $207 \mathrm{kWh} / 10^{6} \mathrm{Btu}$ for $200 \mathrm{psig}$ process steam (12), larqely because it is not a very efficient generator of steam. It is best suitable in applications where high levels of electricity and high temperature steam are required.

- Diesel Engine Topping: This is the type normally used in total energy systems, and they are characterized by very high power to steam ratios (about $400 \mathrm{kWh} / 10^{6} \mathrm{Btu}$ ) and low grade reject heat, some of it unsuitable for recovery. The FCP is in the 6000-7000 Btu/kWhr range (i.e.. somparatively low efficiency) but its advantage over other systems is in its range of capacities; it is especially well suited for small capacities (as low as $1000 \mathrm{~kW}$ of power requirement) where gas or steam turbines can not be used economically. For higher 
capacities, capital costs tend to be higher than those for gas turbines. Diesel engines are fueled with distillate oil and natural gas, but designs have been made for the use of residual fuel. Research is being carried out to see if a diesel engine can burn coal. (14)

- Steam Turbine Topping Cycle: its advantages are the use of low cost fuels (coal or other such as pulp and paper industry by-products) and high efficiencies of around 75\% (FCP of $4550 \mathrm{Btu} / \mathrm{kWh}$ ). In ordinary industrial steam production a boiler is chosen that generates steam at the pressure to be used--typically in the range of 50 to $350 \mathrm{psig.} \mathrm{In} \mathrm{a} \mathrm{steam}$ cogeneration system this low pressure boiler is replaced by a boiler generating high pressure steam (on the order of 1000 psig or more). The high pressure steam drives a turbine, producing electricity, and the low pressure steam exhausted from the turbine is used for process applications. While the electric generation efficiency is very high, the power-to-steam ratio is relatively low, about $41 \mathrm{kWh} / 10^{6} \mathrm{Btu}$ for $200 \mathrm{psig}$ steam (12) compared to. $207 \mathrm{kWhr} / 10^{6}$ Btu for gas turbine. However, the balance between heat and power demands within particularly energy intensive industries is suitable for steam turbines. In pulp and paper, industrial chemicals and refineries all but $17 \%$ of the electricity would have to be purchased if the steam requirements were met with steam turbines. (13) These characteristics, plus the use of an abundant fuel as input make these coal-fired systems the most reasonable ones to use in the anal-. ysis in spite of their high capital cost. A. Implementation Schedule

While the institutional barriers to implementation will not be easily resolved, the analysis in the following pages will 
concentrate on potential penetration from the technical aspect. A Dow Chemical report (13) has estimated that "if all of the steam load required in the $400,000 \mathrm{lbs} / \mathrm{hr}$ range (allowing for 20 MW generation capacity) were generated with by-product power, there would be 33,300 MW in 1985." To get a perspective on this amount, installed nuclear capacity in 1974 was $31,662 \mathrm{MW}$ and the installed capacity of industrial self generation about 19,000 MW. Although nuclear capacity essentially rose from zero to its present levels in less than a decade, it is not comparable because nuclear plant sizes are in the 5001200 MW range, while the steam turbine systems discussed are in the 20 MW range. In addition, central plants are installed by utilities in the business of creating energy which is not the case for industrial cogeneration. A better model is the penetration rate for gas turbines, which have a capacity of about 26 MW per unit. In the past seven years (1969-1976) average yearly additions of gas turbines have been about $5200 \mathrm{MW}$. Based on this rough analysis, a penetration rate of some 2000 MW per year, starting in 1978, was chosen for steam turbine topping cycle by-product electricity systems. This yields a total of 14,000 MW by 1985 and some 40,000 MW in the year 2000 .

\section{B. Technical parameters}

At a heat rate of 4550 Blu/kwir, a 20 wiw facility produces $91 \times 10^{6} \mathrm{Btu}(\mathrm{e}) / \mathrm{hr}$. To produce this power, a heat balance from the Dow rupurt ${ }^{(13)}$ chows a requirement of $j \%$ million Btu per hour input at a boiler efficiency of $88 \%$. The process steam output is 418 million Btu per hour at 150 psi. This heat balance is represented below schematically (Figure 6). To convert 
these figures into a yearly output of 40,000 MW installed capacity, a load factor has to be chosen. In Reference 13 this factor is .85 but a utilization factor of .50 was selected since it is closer to the historical value for industrial self generation and also is consistent with one of the electrical demand sectors in the optimization model.

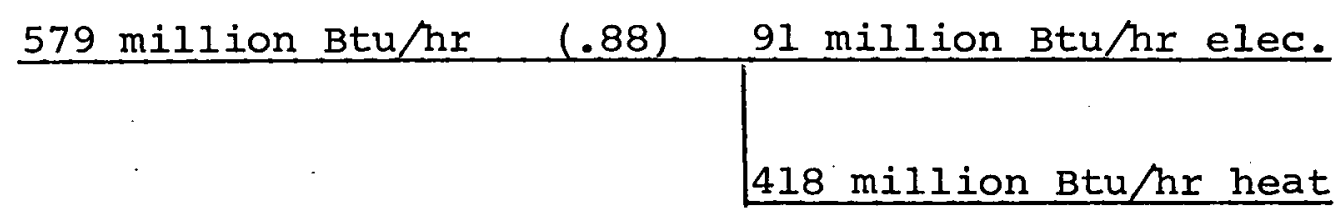

Figure 6: Heat balance, 20 MW steam turbine topping cycle

For two thousand of these units, or 40,000 MW by the year 2000, the annual production of heat and electricity at a load factor of .50 is 3.66 quad and .80 quad respectively, as shown in Figure 7.

5.072 quad $(.88)$ .798 quad electricity 3.666 quad process heat

Figure 7: Heat balance, yearly output of 40,000 MW at L.F. $=.50$ 
The costs used in the analysis are obtained from the cost tables associated with the optimization model. (15) For the capital cost of the installation, figures for coal steam electric plants were obtained from Reference 2 assuming that on the average two $20 \mathrm{MW}$ are installed. It yields $\$ 836 / \mathrm{kW}$, which compares well with the $\$ 900 / \mathrm{kW}$ cited in Reference 14. Although these capital costs appear approximately two times higher than central station plants, this comparison is not valid because not all the capital cost should be accountable to power but shared with the steam generating activity. Transmission and distribution costs were ignored under the rationale that these installations that carry the surplus electricity sold are the same ones that presently exist for purchased electricity. Operation and maintenance costs are assumed to be similar to central station plants $\left(\$ 1.12 / 10^{6} \mathrm{Btu}\right)$ and fuel costs are $\$ 16 /$ ton underground and $\$ 14 /$ ton stripmined coal. (15) The total cost fed into the model added up to $\$ 11.77 / 10^{6}$ Btu of electricity generated by cogeneration, and zero costs were assigned to the process heat generated.

c. Model Run Results

Cogeneration was introduced into the BESOM model as a new supply technology generating electricity that goes to meet demand for intermediate electricity with a cost of $\$ 11.77 / 10^{6}$ Btu. For each million Btu of electricity generated 4.6 million Btu of heat are sent to process heat at zero cost. This factor is obtained from the heat balanne in Figure 7. The model results show a savings in total resources consumed of 4.1 quads and an increase in coal consumption of 2.01 quads. The 5.2 quads of coal that go to cogeneration displace enough central 
electric capacity to produce these favorable results. Coal fired steam electricity generation is reduced by $26 \%$ and oil to process heat is reduced by $35 \%$, all of which are replaced at the high oil prices in the model by heat from cogeneration. The high marginal value for this electricity, $\$ .756 / 10^{6}$ Btu shows the desirable economics of increased capacity, but under the system efficiency described here, the demand for process heat at these loads and temperature are the upper bound on capacity expansion. To arrive at more accurate figures for the maximum potential installed capacity, the projections of demand for process heat will have to be disaggregated by temperature, pressure, and load. At present, this level of detail has not been estimated for the year 2000 demands, thus the cogeneration potential should be considered tentative. 


\section{THIS PAGE}

\section{WAS INTENTIONALLY LEFT BLANK}




\section{II-3. TRANSPORTATION SECTOR}

Fuel savings in the transportation sector appear to be the most visible short term conservation activity in our energy system. The automobile, which alone consumed $18 \%$ of the total energy resources in 1975, can achieve efficiency increases of $100 \%$ for the fleet average and it is so legislated in the Energy Policy and Conservation Act (21) . By the year 2000, the fleet average will have been raised from 13.5 $\mathrm{mpg}(1972$ ) to $25.0 \mathrm{mpg}$ (3); assuming that the efficiencies stipulated in the Act for model year 1985 are sustained. A list of other conservation measures in the transportation sector includes:

- Passenger cars and light trucks: speed limits, vehicle maintenance, car-pooling, design changes (reduced aerodynamic drag and rolling resistance, weight reductions and modified engines), mode shifts.

- Air: cruise speed reductions, improved traffic control, load increases (i.e., flight reductions).

- Freight trucking: modified regulations concerning weight limits and routes, mode shifts.

- Ships: minimize port turnaround time, boiler maintenance.

Estimates of fuel impact can be made on an item by item basis but usually the savings will not be additive. In general, there are complexities in an evaluation of the transportasector that make it critical to have a detailed baseline. The projections already published by the National Center (2) were found to be insufficiently detailed and the following section 
contains a new set that borrows heavily on work done by the Institute for Energy Analysis ${ }^{(18)}$ (which in turn is based on work done for Project Independence). The level of services (passenger-miles and ton-miles) and efficiencies (Btu/passenger mile and Btu/ton-mile) are specified as well as the mode shifts and efficiency improvements vis a vis 1972.

A. Demand to the Year 2000

The transportation sector is best analyzed by separating passenger and freight services by mode--auto, bus, truck, rail, air and ship. This treatment fails to account explicitly for such non-highway uses of transportation fuels as farm machinery, lawn mowers and so on but they are small. Also left out is military transportation and fuel for pipelines, both of which are included in the Bureau of Mines (20) accounting of fuels to this sector. The use of natural gas in pumping stations for oil and gas pipelines is tied to the amounts of domestic production and importation of these fuels and is best treated as a transmission loss in analyses of the supply sector. The use of electricity in oil pipelines is omitted from the transportation sector by the Bureau of Mines and is presumably accounted for in miscellaneous electric drive uses. The use of fuels by military transportation can be added to the baselines independent of the total passenger-mile and ton-mile growth rates for the rest of the sector. In 1972 the consumption by military transportation was 851 trillion $\mathrm{Btu}$, of which $63 \%$ was for jet fuel, $32 \%$ for diesel and residual, with the rest going to gasoline ${ }^{(19)}$.

Presented here are four projections of energy demand in the transportation scctor to the ycar 2000 based on growth rates 
for services, efficiency increases and mode distributions presented in (18). All share the same growth rates (for transportation services) and the two principal ones have essentially the same efficiencies but differ drastically in mode shares. one is a "baseline" and follows historic trends in mode shares while the other is a "mode shift" case that evaluates the impact of wholesale shifts away from intercity auto to bus and from intercity truck to rail (for freight). The fuel efficiency for automobile in (18) does not incorporate the increases specified in the Energy Act and so two additional cases are included, a "baseline with $25 \mathrm{mpg}$ auto fleet" and a "mode shift with $25 \mathrm{mpg}$ auto fleet". Table 22 presents the growth rates for transportation services, Table 23 the efficiencies and Table 24 the mode shares for 1972 and 2000. Table 26 summarizes the energy demand for all four cases.

The yearly growth rates for transportation services are $2.9 \%$ for passenger miles, $2.4 \%$ for ton-miles and $3.0 \%$ for nonfreight trucking, from reference (18). Comparison with historical rates show that passenger travel grew at 5.2\% between 1964 and 1972, with rail and bus travel experiencing negative growth and air travel showing a very high rate increase of $13 \%$ for that period. This activity, however, is completely dominated by the automobile, and a justification for a reduction of the historical 5.2\% yearly growth (identical to the rate for all. passenger travel) is included in a later paragraph in this section. Freight ton miles grew at $3.6 \%$ per year for the $1962-$ 1972, but eliminating pipelines (transporting oil) the rate falls to $2.8 \%$ per year. This is only slightly higher than the $2.4 \%$ growth to 2000 assumed here and it falls to $2.3 \%$ if pipelines are omitted. Slower exponential growth is expected over 
a long time span of more than 25 years because of various saturations (population growth, traffic congestion, air quality degradation and so on).

The efficiency improvements are significant but are probably smaller than the maximum possible. Table 25 shows the unit energy decreases between 1972 and the 2000 values used for the "baseline". These are taken from the $\$ 7 / \mathrm{bbl}$ scenario for 1985 in the Project Independence Report (19); the efficiencies in the "mode shift" case are slightly higher and are taken from the \$1l/bbl scenario for 1985 in the same source. The improvements are to be viewed largely as management type measures responsive to price increases. Essentially no new technologies are introduced.

The changes in mode shares from the historical base year to 2000 for the "baseline" include a large relative increase in air, from $6.8 \%$ to $13.6 \%$ of total passenger miles and from $.3 \%$ to $.8 \%$ of total ton miles, at the expense of intercity auto and rail freight. Truck freight also increases its share ( $16 \%$ to $20 \%$ ) while bus and rail passenger traffic remain essentially at their historical levels. The "mode shift" case is best viewed as an exercise on the impact of large changes in transportation use patterns. All intercity auto traffic is assumed to be replaced by bus or a public transport mode of equivalent Btu/pass mile value; one half of the local auto traffic is also met by bus. Air travel's share is decreased from "baseline" lcvelo (it atill ia higher than the 1972 base) for both passenger and freight. Finally, intercity truck freight is all switched to rail or a mode with equivalent Btu/ ton value. 
Table 22: Projected Growth, Transportation Sector

$\begin{array}{lrr} & 1972 & 2000 \\ \text { Total Passenger Miles (billion) } & 2,602 & 5,776 \\ \text { Total Freight Ton Miles (billion)* } & 2,846 & 5,522 \\ \text { Total Non-Freight Vehicle Miles (billion) } & 112 & 259 \\ \text { Growth rate, pass-miles, 1972-2000 } & 2.9 \% \\ \text { Growth rate, ton miles, 1972-2000 } & 2.4 \% \\ \text { Growth rate, vehicle miles, 1972-2000 } & 3.0 \%\end{array}$

*Includes ton miles of petroleum carried in pipelines but the natural gas and electricity that is consumed is omitted in the analysis. 


\section{Table 23: Transportation Efficiencies}

$1972 \begin{array}{cc}2000 & 2000 \\ \text { Baseline } & \text { Mode Shift }\end{array}$

Passenger

(Btu/pass-mile)

$\begin{array}{lrrrr}\text { Air } & 7,899 & 6,748 & 6,387 \\ \text { Auto local } & 5,329(12.0 \mathrm{mpg}) & 4,276(15.0 \mathrm{mpg}) & 4,234(15.2 \mathrm{mpg}) \\ & \text { interrity } & 2,526(18.3 \mathrm{mpg}) & 2,099(22.9 \mathrm{ilpy}) & \\ \text { Bus local } & 1,704 & 1,550 & 1,550 \\ & \text { intercity } & 1,160 & 1,155 & 1,155 \\ \text { Rail local } & 2,960 & 2,382 & 2,377 \\ & \text { rapid rail } & 904 & 900 & 898 \\ & \text { intercity } & 2,983 & 2,392 & 2,392\end{array}$

Freight

(Btu/ton mile)

\begin{tabular}{|c|c|c|c|c|}
\hline Air & & 26,162 & 24.771 & 24,500 \\
\hline 'I'ruck & $\begin{array}{l}\text { local } \\
\text { intercity }\end{array}$ & $\begin{array}{l}7,139 \\
2,604\end{array}$ & $\begin{array}{l}6.945 \\
2.233\end{array}$ & $\begin{array}{c}6,726 \\
-\end{array}$ \\
\hline Rail & & 709 & 630 & 630 \\
\hline Ship & & 567 & 573 & 57 \\
\hline
\end{tabular}

Non-Freight

Trucking $13,000(9.6 \mathrm{mpg}) \quad 13,000(9.6 \mathrm{mpg}) \quad 13,000(9.6 \mathrm{mpg})$ (BLu/vehicle milc) 
Table 24: Decreases in Unit Fuel Consumption

$\underline{\text { Passenger }}$

Period of 1972 to Baseline 2000

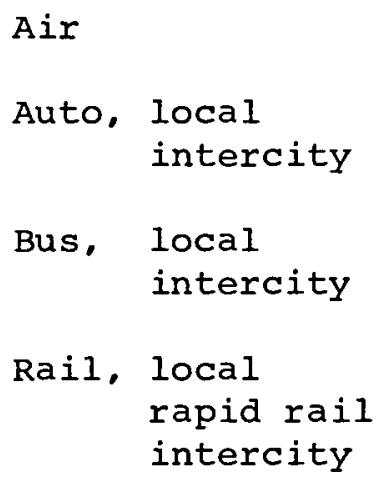

Air

Auto, local intercity

Bus, local

intercity

Rail, local

rapid rail

intercity

$$
\begin{aligned}
& -14.6 \% \\
& -19.8 \% \\
& -20.1 \% \\
& -9.0 \% \\
& -- \\
& -19.5 \% \\
& -- \\
& -20.0 \%
\end{aligned}
$$

Freight

Air

$-5.3 \%$

Truck, local

$-2.3 \%$

intercity

$-14.2 \%$

Rail

$-11.1 \%$

Ship

Non-Freight Trucking 
Table 25: Transportation Mode Shares

$\underline{1972} \quad \begin{array}{cc}2000 & 2000 \\ \text { Baseline } & \text { Mode Shift }\end{array}$

\section{Passenger}

(percent of pass-miles)

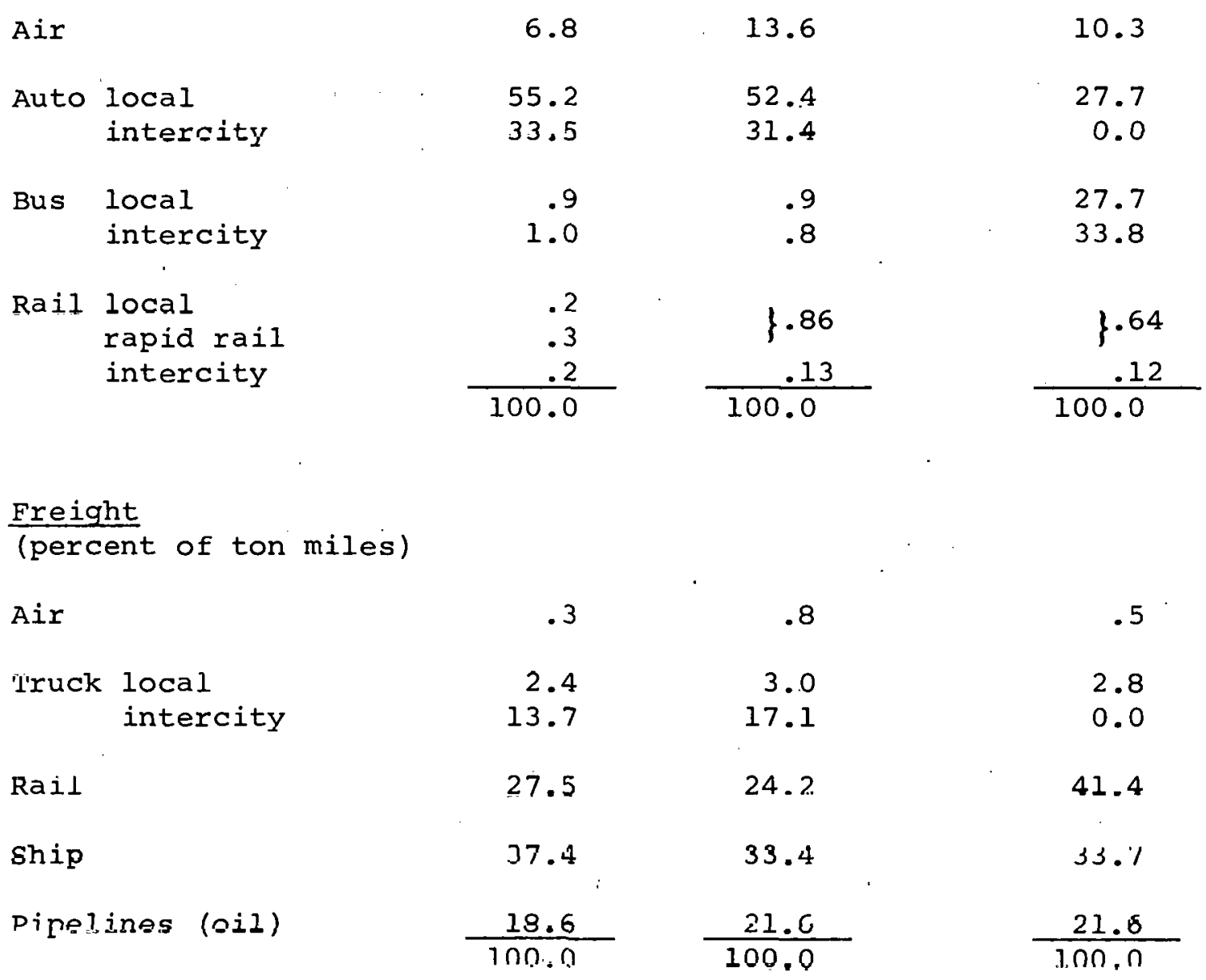


Comparison of Year 2000 Demands with Other Projections

The resulting energy demands (the summation of passenger miles and ton miles by the percent shares and the mode efficiencies) are summarized in Table 26. The "baseline" totals 31.8 quad and the "mode shift." case 22.8 quad for a decrease of $28 \%$. This significant drop is achieved under extreme conditions, i.e., it can be seen as a sort of boundary gain for mode switching.

The incorporation of a $25 \mathrm{mpg}$ automobile fleet results in a 15\% drop in energy demand in the "baseline". from 31.8 quad to 27.0 , and of $9 \%$ in the "mode shift" case, from. 22.8 to 20.8 quad. The latter gains are smaller because of the diminished role of the automobile in this case, but in both cases it reflects an increase in efficiency from $17.9 \mathrm{mpg}$ to $25.0 \mathrm{mpg}$. It is important to point out at this point that the "baselines" already include efficiency gains from 1972 levels, listed in Table 24. They range from $20 \%$ in passenger rail, $15 \%$ in air and $14 \%$ in trucks to rather small improvements in bus transit. These improvements are only due largely to load factor increases, stock modernization and other management-type measures.

At this time, no major government $R \& D$ conservation funds are going to modes other than auto and truck. It is significant that the mode with the largest potential for further efficiency increases is the automobile. Based on the results in this analysis, for every $1 \mathrm{mpg}$ gain for the fleet average, energy to the transportation sector drops by $2 \%$.

Areas not analyzed are the replacement of engines using conventional fuels by stirling engines or turbines that can use a large range of fuels, and electric vehicles. It is felt that an assessment of these technologies is beyond the scope 
Table 26: Energy Demand: Transportation Sector, $2000\left(10^{12} \mathrm{Btu}\right)$

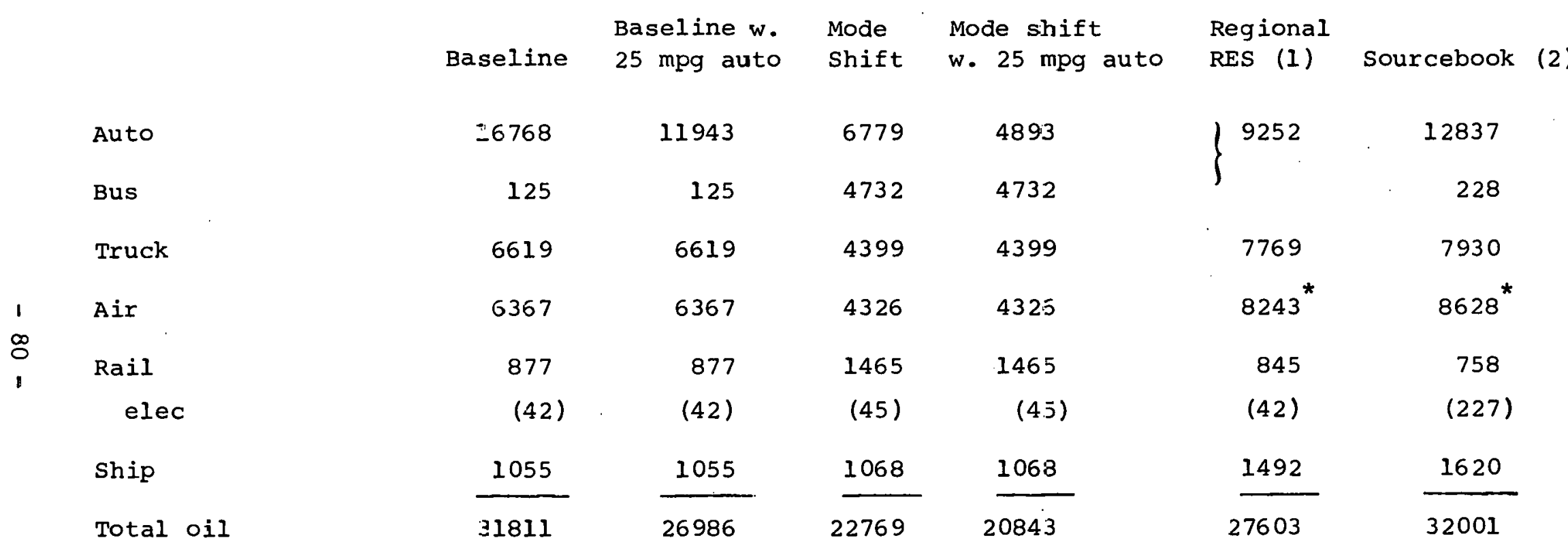

*Includes military jet fuel.
(1) Reference (3)
(2) Reference (2) 
of this analysis; their implementation and economics are tied to new configurations of the energy supply system such as availability of inexpensive off peak power or production of methanol. Furthermore, the state of the art for these new engines does not provide for higher fuel efficiency.

Also included in Table 26 for comparison purposes are the projections in BNL's Sourcebook for Energy Assessment (2), which do not incorporate the legislated auto fuel efficiencies, and those in the Regional Reference Energy systems (3), which do. It can be seen that these compare well with the corresponding "baselines" projected here. C. Discussion of Demand Projections

The area where uncertainties arise in this projection of energy use in the transportation sector is the growth rate in level of services (passenger miles, ton miles) specified in Table 22. The following remarks on selected modes shed some light on the biases implicit in these values.

- Automobile: the baseline projects 4840 billion passenger miles or 18300 miles per capita per year. This results in a $2.0 \%$ yearly growth rate from 1972 and is equal to the per capita rate in the 1970-1972 period (down from 3.8\% in 19621970). What is not reflected, though, is an effective saturation. At an average speed of 33 mph. (historical), we obtain an average daily time spent in an automobile of over 90 minutes per person, versus a present figure of about 50 minutes. Such a large increase can hardly seem realistic unless leisure time increases rapidly and a large fraction of it is spent 
driving. Assuming that automobile travel levels off at 14,400 passenger miles per year (the midpoint between present levels and the projected one), total consumption drops $21.5 \%$ to 13.2 quads.

- Air, passenger travel: the growth in passenger miles per capita is computed to be $4.6 \%$ for the period 1972-2000. Historical rates were $7 \%$ in $1950-1960,16 \%$ in $1960-1970$ and $2 \%$ in $1970-1974$. Demand for air travel is strongly tied to personal income and the 1974 figures reflect the embargo and the start of the recession, but growth similar to that during the sixties is unlikely to recur. The infrastructure required to support this increase in air travel implies the introduction of larger aircraft than exist presently and/or the construction of large new airports. None of this is foreseen so these air travel figures may be high.

- Freight transportation: the projections of demand for freight ton miles is intricately linked to the overall supply and demand configuration for energy. Fully $36 \%$ of the total ton miles transported in 1972 were oil producto, and coll amounted to $8 \%$ oil moved primarily by pipelines (50\%) and uver waterways (41\%), while coal was mostly transported by rail. (7n,6) with the rusl larycly over water (18\%). There are differences in efficiencies (Btu/ton mile) among these modes, and a significanl shift from 011 to coal in the U.S. energy mix will impact the modal distribution and the 
total energy consumed by freight. An increase in coal production to 33.7 quad by 1990 would raise its share of the total freight movement from $8 \%$ to $12 \%^{(19)}$. A "business as usual" growth for petroleum products would result in a total demand of some 50 quads, leaving its share of the total at essentially historical levels (38\%), but effective conservation and substitution by other energy sources should decrease this value considerably. Thus, baselines in freight transportation are subject to second order modifications resulting from conservation measures and different supply alternatives.

- Efficiency improvements: it is not unlikely that the decreases in unit fuel consumption can go beyond those presented in Table 25. Between 1972 and 1974 alone, Department of Transportation statistics $(22)$ indicate decreases of $13 \%$ in Btu/passenger mile for certificated air carriers, of $6 \%$ in $\mathrm{Btu} / \mathrm{ton}$ mile for diesel railroads and of $5.5 \%$ in Btu/ton mile for trucks. Although these figures are obtained in an approximate fashion from ratios between fuels consumed and performance levels, they are large enough to indicate the size of gains due to management activities as a response to the embargo and higher prices. Similar data yields no gain in Btu/passenger mile for the automobile, where options such as increased loading do not exist. 
- Changes for Conservation II and Revised Growth cases: calculation with advanced efficiency improvements were made using the level of services and mode shares in the "baseline". These are presented in Table 27, and consist of a $29 \mathrm{mpg}$ auto fleet, $12 \mathrm{mpg}$ for light trucks (up from $9.6 \mathrm{mpg}$ in 1972) and decreases in unit fuel consumption of 20-30\% (from 1972 values) for other modes. This results in a total fuel decrease of $24.5 \%$ (below the "baseline") to 24.0 quads, and when the limit of 14,400 passenger mile per person is introduced, there is a further drop to 21.6 quads. The transportation sector in 1975 consumed 17.6 quads of oil. Adjusting for a consumption by the military of .8 quads (ignored in the projections), we obtain a yearly growth rate of only $1.0 \%$ for the lowest case. This is the growth incorporated in Conservation II and Revised Growth cases appearing in Figures 4 and 5 . 
Table 27: Transportation Sector, Advanced Decreases in Unit Fuel Consumption

Unit Fuel Consumption

Energy Demand

(Quad)

\section{Passenger}

Auto

Air

Bus

Rail

Freight

Air

Truck

Rail

Ship

Non-Freight

Trucking
(29 $\mathrm{mpg})$

$-30 \%$

unch .

unch.

$-20 \%$

$-20 \%$

$-20 \%$

unch.

(12 mpg)
$10,350(7,967) *$

4,343

125

877

901

2.907

756

1,055

*Assuming a yearly 14,400 pass-mile per capita. 


\section{REFERENCES}

1. Arthur D. Little, Inc., "An Impact Assessment of ASHRAE Standard 90-75, Energy Conservation in New Building Design", Report to FEA C-78309, 2nd printing, March 1976.

2. Beller, M., Ed., "Sourcebook for Energy Assessment", NCAES, Brookhaven National Laboratory, BNL 50483, December 1975.

3. Hermelee, A., "Regional Reference Energy Systems", to be published.

4. Project Independence Task Force Report, "Residential and Commercial Energy Use Patterns 1970-1990", Vol. 1, Federal Energy Administration.

5. Dolc, E. H., "Encrgy Uac and Conservation in the Residential Sector: A Regional Analysis", The Rand Corporation, R-1641-NSF, June 1975.

6. Petersen, S. R., "Retrofitting Existing Housing for Energy Conservation: An Economic Analysis Center for Building Technology", National Bureau of Standards, 1975.

7. Community Services Administration, "A Community Planning Guide to Weatherization", September 1975.

8. Woodham, W., Owens Corning Fiberglass (private communication).

9. Licht, E., Architect (private communication).

10. Cherniavsky, E. A., "Brookhaven Energy System Optimization Model, Topical Report, "Brookhaven National Laboratory, BNL 19569, December 1974.

11. Spencer, R. S. did Decker, G. L.," Erieryy and Capltal Cionservation through Exploitation of the Industrial steam Base;" The Dow Chemical Company, presented at Energy Conservation; $\Lambda$ National Forum, Dccombcr 1975 .

12. Nydick, S. E. et al., "A Study of Inplant Electric Power Generation in the Chemical, Petroleum Refining and Paper and Pulp Industries," Thermo Electron Corp. Report No. TE 542997-76, 1976. 
13. The Dow Chemical Company, "The Energy Industrial Center Study", Grant No. OEP74-20242, June 1975.

14. Williams, R. H., "The Potential for Electricity Generation as a Byproduct of Industrial Steam Production in New Jersey," Center for Environmental Studies, Princeton University, June 1976.

15. Beller, M., "Updated Cost Tables for Expanded LP Model," BNL Report No. ESAG-16, April 30, 1974.

16. Seidel, M., "Economic Benefits of Energy Conservation," delivered at Energy Conservation: A National Forum, (Ft. Lauderdale December 1-3, 1975) February 19, 1976.

17. Allen, E. H., "The Business of Saving Energy", prepared for the Workshop of Energy Extension Services, July 1976, University of California at Berkeley.

18. Institute for Energy Analysis, "The IEA Energy Simulation Model, A Framework for Long-Range U.S. Energy Analysis, Oak Ridge Associated Universities, January 1976.

19. Project Independence Task Force Report, "Project Independence and Energy Conservation: Transportation Sector", Volume 2, Federal Energy Administration, November, 1974.

20. U.S. Bureau of Mines, Department of Interior, "Minerals Yearbook" yearly publication.

21. Ninety-Fourth Congress, First Section, Energy Policy and Conservation Act, Conference Report No. 94-516, Washington D. C., December 8, 1975.

22. U.S. Department of Transportation, "Summary of National Transportation Statistics, Annual Report," June 1976 (also June 1974).

23. National Petroleum Council, "Potential for Energy Conservation in the United States; 1974-1978", September 1974.

24. United Nations Economic and Social Council, Economic Commission for Europe; "Study on Measures Taken, or Which Might be Taken, to Achieve Increased Economy and Efficiency in the Extraction, Conversion, Transport and Use of Energy in the ECE Region", E/ECE/833, February 1975. 
25. Shipper, L., "Towards More Productive Energy Utilization, Energy \& Environment Division", LBL-3299, October 1975.

26. Seidel, M. H., "The Regional Impact of Industrial Fuel Use", September 1975.

27. Behling, D. J., Dullier, R., Hudson, "The Relationship of Energy Growth to Economic Growth under Alternative Energy Policies", BNL 50500, Economic Analysis Division, Department of Applied Science, Brookhaven National Laboratory, March 1976.

28. Hirst, E. et al., "An Engineering - Economic Model of Residential Energy Use" Oak Riḍge National Laboratory, ORNL/TM-5470, May 1976. 
APPENDIX A: REFERENCE ENERGY SYSTEM AND BROOKHAVEN'S ENERGY SYSTEMS OPTIMIZATION MODEL

A Reference Energy System consists of a set of estimated energy demands, energy conversion technologies, fuel mixes, and the resources required to meet those demands. The pictorial format for the Reference Energy system is a network diagram which indicates energy flows and the associated conversion efficiencies of the reference technologies employed in various stages of the energy production/transmission/distribution/end-use system. Technologies are characterized by parameters which include capital, operating and fuel costs, energy conversion efficiencies and environmental emissions.

As illustrated in Figure 2 each path through the energy system network indicates a possible route for the flow of energy from an energy resource to a given demand category. Alternate paths and branches reflect the substitutability of various resources and technologies for one another. The energy flowing through each step or process is shown above the line representing the activity. The numbers in parentheses are the efficiencies, or relative effectiveness, of the processes. The RES representation permits calculation of the amount of a particular energy resource, e.g., oil, used to satisfy a particular demand, e.g., space heating, either through a particular intermediate fuel form, such as electricity, or directly. Energy demands are assumed for each reference year from historical data and projections.

The values on the right side of the RES under the heading "Demand Category" represent the basic energy demands in terms of a specific set of end-use categories. These basic energy 
demands should be distinguished from the more commonly used fuel demands. They represent the net energy required to provide a given level of service, e.g., for maintaining room temperatures at $72^{\circ} \mathrm{F}$, and are derived from amounts of fuel and efficiencies of utilizing devices. They are useful both conceptually since they represent more closely the level of service rendered by energy use, and for purposes of projection since they are direct1y related to underlying causative factors, e.g., number of houses to be heated, vehicle miles traveled, etc., and are independent not only of the fuel source but also the efficiency of the conversion device. These efficiencies are shown under the heading "Utilizing service". In general, a strict improvement in conversion efficiency, e.g., and engine tune up or upgrading a boiler design, is characterized by an increase in this value, while a change in basic energy demand represents an effective change in the quantity of heat and power required by the system. For a given level of services (linked to an exogenously determined GNP growth rate), cutbacks in basic energy demands can be obtained, for example, by improved design of buildings or the development of new processes in the manufacture of a ton of aluminum. For the transportation sector the clear distinction between conversion efficiency and basic energy demand breaks down and an exception is made (for example, the conversion efficiency from chemical to motive energy in a gasoline engine is about $15 \%$ or less, the rest being dissipated as heat; this concept is quite independent of the "miles per gallon" efficiency by which auto performances are usually measured).

The Brookhaven Energy System Optimization Model (BESOM)

is a linear programming model in which the total cost of satisfying a given set of national energy demands is minimized. 
Given a set of energy requirements defined by end use (i.e., motive power, space heat, electric power) and a set of available energy resources and conversion technologies, the model determines the minimum cost allocation of energy supplies to meet energy demands. For instance, it determines the annual coal and oil requirements of electric generating plants, the quantities of oil and electricity directed to space heat, and the refined oil/electricity mix to meet the demand for motive power.

The important characteristics of the model may be summarized as follows:

(a) The model emcompasses the entire energy system including all alternate resources and both electric and nonelectric demands.

(b) The full feasible range of interfuel substitutability in providing for end use energy requirements (e.g.., space heat) is reflected.

(c) Technical, economic, and environmental characteristics of energy conversion devices (both supply and utilization) are incorporated.

(d) The load-duration characteristics of electrical demands are included. (This is a very important element that is ixequently ignored in energy system modelling.)

(e) Supply, demand, and environmental constraints are specified exogenously.

(I) Optimal supply-demand configurätions are indicated by the mode1. The optimization may be performed with respect to cost, resource consumption, or environmental effects in a given planning year, or with respect 
to some arbitrary combination of these factors. It should be noted that the optimization is performed on the basis of annual cost in the planning year rather than a minimum present worth over some number of years or over a planning increment.

(g) The model also includes sensitivity analysis routines which permit economic interpretations of changes in various parameters, and the effects that these changes would have on the optimal solution. If the supply or demand coefficient associated with each variable is changed by a sufficiently small amount, the optimum solution doesn't change. This maximum permissible change can be obtained, together with information on how the solution will differ if a greater change is made. The model also provides for sensitivity analysis in terms of the marginal value of each supply. The marginal value is the rate at which the cost of the optimal solution would decrease per additional unit of that supply made available. Similarly, the marginal value of each demand constraint is calculated. This is the rate at which the cost of the optimal solution would increase per additional unit of a particular demand. The evaluation of these marginal values and costs provides an aid in ascertaining which resources are most needed and which energy demands are most expensive to satisfy.

The model is formulated about the classical transportation problem of determining the optimal routing of a product, in this case an intermediate energy form, from a set of $n$ supply nodes to $m$ demand nodes where a cost and a set of environmental impacts 
are identified for a unit of energy passing over each of the $\mathrm{n} \times \mathrm{m}$ possible paths. The typical linear programming representation of the transportation problem is modified by the inclusion of efficiency coefficients in the supply and demand constraints and is augmented by additional constraint equations reflecting the environmental factors as well as certain technical features of the energy system.

The $\mathrm{n}$ supply nodes and $\mathrm{m}$ demand nodes can include all supply and demand categories. To provide a feasible path between a supply and a demand category, both a supply and a utilizing technology must be identified. For a given path, j, a resource $s_{u}$ is converted to intermediate energy form, $z_{j}$, at an efficien$c y, e_{u j}$. In turn, the intermediate energy form is used to satisfy demand $D_{v}$ at an efficiency $d_{v j}$. Each intermediate energy form contributes to a set of air pollutants $\mathrm{B}_{\mathrm{w}}$ in accordance with emission coefficients, $f_{w j}$. Additional constraints $G_{y}$ are placed on certin plant capacities and on electrical peaking and balance requirements. A cost $c_{j}$ is also defined per unit of intermediate energy form.

In the model, the intermediate energy form is defined at the point just before end use. Intermediate energy forms include transmitted and distributed electricity, gasoline in an automobile, oil in a home oil tank, for example. The supply efficiency is calculated by multiplying together all the supply efficiencies on a path from the resource to the intermediate energy form; similarly, the demand efficiency is calculated by multiplying together all the demand efficiencies on the path from the intermediate energy form to final demand. The efficiencies and environmental impacts associated with each activity in BESOM are taken from the Energy Model Data Base maintained at Brookhaven. 